\title{
Information Immobility and Foreign Portfolio Investment
}

\author{
Sandro C. Andrade \\ University of Miami \\ Vidhi Chhaochharia \\ University of Miami
}

\begin{abstract}
We examine how residents of the United States allocate their stock portfolios internationally. We find that a large U.S. Foreign Direct Investment (FDI) position in a destination country in 1990 is associated with a relatively large stock portfolio position in that country in the 2001-2006 period. Moreover, a change in the U.S. FDI position from 1980 to 1990 helps predict the change in the U.S. Foreign Portfolio Investment position from 1994 to 2006. These results are rationalized by Van Nieuwerburgh and Veldkamp's (2009) equilibrium model of learning and portfolio choice under an information processing constraint. FDI establishes marginal differences in the endowments of information about different countries, which later translate into differences in stock portfolio holdings. We control for cross-country differences in capital controls, proximity along different dimensions, corporate governance, and economic and capital market development. Our results also hold for the G6 countries collectively. (JEL F21, F36, G11)
\end{abstract}

How do investors allocate their stock portfolio internationally? The capital asset pricing model (CAPM) under purchasing power parity predicts that all investors hold the World Market Portfolio regardless of their nationality (Grauer, Litzenberger, and Stehle 1976). This prediction, however, is clearly at odds with the data (Karolyi and Stulz 2003), indicating that investors take into account factors other than the benefits of international diversification. Economists need alternative theories to describe how investors allocate their portfolios internationally.

An important family of models asserts that cross-country differences in stock portfolio allocations arise because investors in different countries are endowed with different information sets (Gherig 1993; Brennan and Cao 1997; Kang and Stulz 1997). A long-standing conceptual difficulty with this argument is that information asymmetry would not be sustainable for long peri-

\footnotetext{
We are grateful to Geert Bekaert (the Editor) and two anonymous reviewers for excellent suggestions. For helpful discussions, we thank Gennaro Bernile, Stijn Claessens, Doug Emery, Michael Fuerst, Andrew Karolyi, Sergei Sarkissian, Robert Vermeulen, and seminar participants at the 2008 Australasian Finance and Banking Conference. For sharing their data, we are grateful to Geert Bekaert, Menzie Chinn, Luc Laeven, Philip Lane, Rafael La Porta, Ross Levine, Gian Maria Milesi-Ferretti, Srobona Mitra, Dennis Quinn, and Siddharth Sharma. All errors are ours. Untabulated regression results are available upon request. Send correspondence to Sandro C. Andrade, School of Business Administration, University of Miami, P.O. Box 248094, Coral Gables, FL 33124; telephone: (305) 284-8819. E-mail: sca@miami.edu.
}

(C) The Author 2010. Published by Oxford University Press on behalf of The Society for Financial Studies. All rights reserved. For Permissions, please e-mail: journals.permissions@ oxfordjournals.org. doi:10.1093/rfs/hhp116 
ods due to investor incentives to acquire knowledge about the information sets of other investors. In recent work, Van Nieuwerburgh and Veldkamp's (2009) address this difficulty by modeling the information and portfolio choice problems simultaneously, while subjecting investors to plausible information processing constraints. Investors in their model are endowed with a small degree of asymmetric information about assets and have a "learning budget" to be allocated across assets. In a rational expectations equilibrium, investors want to make their information sets unique, in order to buy low-priced assets that other investors consider risky, due to a lack of information about them. Therefore, instead of choosing to learn about assets they know relatively little about, investors choose to specialize in assets in which they have an initial informational advantage. This behavior amplifies rather than dissipates initial differences in information endowments across investors and can explain why small differences in endowment of information may produce large and long-lasting cross-country differences in portfolio allocations.

In order to bring Van Nieuwerburgh and Veldkamp's (2009) theory to the data, we use a country's past weight in the U.S. foreign direct investment (FDI) portfolio as a proxy for that country's share in the U.S. information endowment. We conjecture that, relative to world investors, U.S. investors were initially better informed about countries in which there was more U.S. FDI. ${ }^{1}$ The assumption that investors obtain enhanced information after FDI takes place is central to the FDI theory in Razin, Sadka, and Yuen (1998, 1999), Goldstein and Razin (2006), and Razin and Sadka (2007). ${ }^{2}$ Moreover, we show that past U.S. FDI is indeed associated with current proxies of information flow between the United States and other countries.

Our results provide empirical support to Van Nieuwerburgh and Veldkamp's (2009) theory. We find that a country's weight in the U.S. FDI position in 1990 explains that country's weight in the U.S. stock portfolio from 2001 to 2006. Moreover, a change in a country's weight in the U.S. FDI position from 1980 to 1990 helps predict the change in that country's weight in the U.S. FPI position from 1994 to 2006. In contrast to most of the empirical literature in international portfolio choice, we show that our empirical results hold not only for U.S. foreign holdings but also for holdings of the G6 (G7 minus Italy) source countries collectively. The weight of a destination country in a source country's 1990 FDI position explains the weight of that country in the source country's stock portfolio in the 2001-2006 period.

1 The main conceptual difference between FDI and foreign portfolio investment (FPI) is that FDI comes with control in addition to ownership. In practice, FDI is defined as an equity investment corresponding to more than $10 \%$ of the total equity in the target enterprise.

2 Razin, Sadka, and Yuen (1999) state: "Through the stationing of managers from the headquarters of multinational firms in the foreign direct establishments in the destination countries under their control, FDI investors can monitor closely the operation of such establishments, thus circumventing informational problems." Goldstein and Razin (2006) and Razin and Sadka (2007) focus on explaining the contemporaneous choice between FDI and FPI. In contrast, we focus on how early FDI affects later FPI. Our underlying assumption is that, over time, part of the information gathered by FDI investors spills over to FPI investors. 
Other than the endowment of information, Van Nieuwerburgh and Veldkamp's (2009) model indicates that two other variables affect international portfolio allocation. First, investors allocate more resources to countries with larger stock markets, ceteris paribus. Size matters for two reasons: because of diversification and market clearing reasons, as in the CAPM, and because investors gain more from learning about assets that are abundant. To facilitate a comparison with existing literature, we measure size by a destination country's weight in the World Market Portfolio. Second, the investors in Van Nieuwerburgh and Veldkamp's (2009) model want to learn about assets whose payoffs are more uncertain from the perspective of the average world investor. In equilibrium, these assets have less informative prices and offer higher expected returns. We use stock return volatility to proxy for asset pay-off uncertainty from the perspective of the average world investor. We find that both size and volatility are positively related to portfolio choice, as the theory predicts, but the statistical significance of volatility is not robust in all our specifications.

The article proceeds as follows: Section 1 provides a description of our data along with summary statistics. We also discuss the battery of control variables used in our regressions and investigate the relationship between current measures of information flow and past FDI weights. Sections 2 and 3 examine the determinants of U.S. and the G6 investors' foreign stock portfolios, respectively. Section 4 presents robustness checks, and Section 5 concludes.

\section{Data}

We use data from several sources. Our main source is the Coordinated Portfolio Investment Survey (CPIS) published by the International Monetary Fund. The data consist of aggregate foreign portfolio holdings for each participating country. Complete data for sixty-seven source countries are available from 2001 to 2006. For each source country, the survey reports portfolio holdings in up to 218 destination countries. Our analysis focuses on the foreign stock holdings of U.S. residents in each of thirty-eight destination countries listed in table 1. Financial centers such as Ireland, Luxembourg, and the Bahamas are excluded, as most portfolio investment nominally directed to these countries is actually routed from there to other destinations (Lane and Milesi-Ferretti 2008). Our destination countries include all the developed countries and major emerging markets for which data on all the explanatory variables were available. Although we focus on U.S. foreign investments, we show that our results extend to the G6 countries collectively. Italy is not included as a source country because its publicly available FDI data are too coarse. Excluding FPI emanating from financial centers, the G6 countries were responsible for $68.3 \%$ of worldwide FPI in 2001-2006.

The main dependent variable is the weight of a destination country in the total U.S. stock portfolio in each year from 2001 to 2006; that is, the total dollar amount of U.S. stock portfolio investments in a country in a given year 
Table 1

Summary statistics

Panel A

\begin{tabular}{|c|c|c|c|c|}
\hline Country & $\begin{array}{c}\text { Stock market } \\
\text { portfolio } \\
(\%) \\
\text { (av. 2001-2006) }\end{array}$ & $\begin{array}{c}\text { World market } \\
\text { portfolio } \\
(\%) \\
\text { (av. 2001-2006) }\end{array}$ & $\begin{array}{c}\text { FDI } 1990 \\
(\%)\end{array}$ & $\begin{array}{c}\text { Stock Return } \\
\text { Volatility } \\
\text { (av. 2001-2006) }\end{array}$ \\
\hline Argentina & 0.006 & 0.276 & 0.681 & 0.295 \\
\hline Australia & 0.354 & 1.772 & 4.066 & 0.008 \\
\hline Austria & 0.041 & 0.209 & 0.299 & 0.013 \\
\hline Belgium & 0.090 & 0.629 & 2.546 & 0.024 \\
\hline Brazil & 0.255 & 0.862 & 3.870 & 0.224 \\
\hline Canada & 1.015 & 2.882 & 18.702 & 0.031 \\
\hline Chile & 0.015 & 0.268 & 0.510 & 0.061 \\
\hline Colombia & 0.002 & 0.068 & 0.451 & 0.178 \\
\hline Denmark & 0.074 & 0.374 & 0.464 & 0.016 \\
\hline Finland & 0.261 & 0.540 & 0.146 & 0.221 \\
\hline France & 0.984 & 4.174 & 5.156 & 0.043 \\
\hline Germany & 0.710 & 3.169 & 7.429 & 0.078 \\
\hline Greece & 0.037 & 0.329 & 0.076 & 0.192 \\
\hline Hong Kong & 0.246 & 2.299 & 1.629 & 0.115 \\
\hline India & 0.129 & 0.933 & 0.100 & 0.124 \\
\hline Indonesia & 0.031 & 0.168 & 0.863 & 0.383 \\
\hline Israel & 0.112 & 0.253 & 0.201 & 0.107 \\
\hline Italy & 0.308 & 1.933 & 3.784 & 0.080 \\
\hline Japan & 1.881 & 9.262 & 6.081 & 0.028 \\
\hline Korea & 0.387 & 1.194 & 0.725 & 0.292 \\
\hline Malaysia & 0.033 & 0.469 & 0.394 & 0.156 \\
\hline Mexico & 0.249 & 0.484 & 2.775 & 0.119 \\
\hline Netherlands & 0.761 & 1.508 & 5.145 & 0.052 \\
\hline New Zealand & 0.022 & 0.092 & 0.849 & 0.044 \\
\hline Norway & 0.095 & 0.358 & 1.133 & 0.049 \\
\hline Pakistan & 0.001 & 0.063 & 0.050 & 0.216 \\
\hline Peru & 0.005 & 0.065 & 0.161 & 0.046 \\
\hline Philippines & 0.014 & 0.113 & 0.365 & 0.177 \\
\hline Portugal & 0.028 & 0.176 & 0.241 & 0.040 \\
\hline Singapore & 0.158 & 0.585 & 1.070 & 0.116 \\
\hline South Africa & 0.118 & 0.984 & 0.209 & 0.091 \\
\hline Spain & 0.310 & 2.162 & 2.117 & 0.066 \\
\hline Sweden & 0.200 & 0.910 & 0.481 & 0.134 \\
\hline Switzerland & 0.839 & 2.226 & 6.753 & 0.031 \\
\hline Thailand & 0.035 & 0.258 & 0.482 & 0.256 \\
\hline Turkey & 0.033 & 0.241 & 0.140 & 0.502 \\
\hline United Kingdom & 2.741 & 7.426 & 19.563 & -0.008 \\
\hline Venezuela & 0.003 & 0.016 & 0.292 & 0.223 \\
\hline Total & 12.583 & 49.730 & 100.000 & 4.823 \\
\hline
\end{tabular}

Panel B

$\begin{array}{ccc}\begin{array}{c}\text { Stock portfolio } \\ \text { weight }\end{array} & \begin{array}{c}\text { World market } \\ \text { portfolio }\end{array} & \text { Stock Return } \\ \text { Volatility }\end{array}$

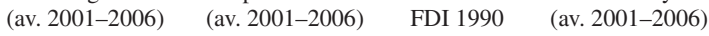

Stock portfolio weight (av. 2001-2006) 1

World Market Portfolio (av. 2001-2006)

FDI 1990

Stock Return Volatility (av. 2001-2006)

0.930
0.841
-0.379

1
0.697
-0.382

1

Panel A presents the time averages of the main variables. The first two columns have the weight of different countries in the total stock portfolio of U.S. residents and in the World Market Portfolio. The third column has U.S. FDI portfolio weights as of 1990. The last column has the Stock Return Volatility in excess of worldwide stock return volatility (as defined in table B1). Panel B presents the correlations among the time averages of panel A. 
divided by the total dollar amount of stocks held by U.S. residents in that year. This is the same dependent variable used by Dahlquist et al. (2003). The total dollar amount of stocks held by U.S. residents is the total market capitalization of the U.S. market (from the World Bank database) plus the total dollar amount of U.S. stock investments abroad, net of the total stock portfolio investment by foreigners in the United States. We do not collapse the data across the time-series dimension because there is nonnegligible time variation in the stock portfolio weights from 2001 to 2006. On average, a destination country experiences a $12 \%$ change in its average weight from $2001-2003$ to 2004-2006.

Our novel explanatory variable is the weight of each destination country in the U.S. FDI position as of 1990. Note that we use 1990 FDI weights to explain equity portfolio weights from 2001 to 2006. The weight is calculated as the ratio of the stock of U.S. FDI investment in each destination country in 1990 divided by the total stock of U.S. FDI in 1990. The stock of U.S. FDI in different destination countries is from the United Nations Conference on Trade and Development's (UNCTAD) FDI database, which was also used by Daude and Fratzscher (2008). The year 1990 is the earliest available for the United States in the UNCTAD FDI database. When we extend our results from the United States to the G6 countries collectively, we also use the earliest FDI year for each G6 country in the UNCTAD database. The earliest year varies slightly by G6 country, ${ }^{3}$ but we will refer to the data as 1990 FDI weights for all G6 countries for simplicity.

The theory in Van Nieuwerburgh and Veldkamp's (2009) informs the choice of two additional variables: the weight of destination countries in the World Market Portfolio and the volatility of stock returns in destination countries. The weight in the World Market Portfolio is calculated using the World Bank's stock market capitalization database in each year from 2001 to 2006. The volatility of stock returns is calculated using monthly total returns on the Morgan Stanley Capital International (MSCI) index of each of the destination countries in the previous five years. For example, we use monthly data from 1996 to 2000 to compute the volatility of stock returns in 2001. In order to mitigate the effect of changing worldwide volatility over the sample period, each year we subtract the return volatility of the MSCI world index in the previous five years from the country-level volatility. Returns are measured in U.S. dollars in our baseline regressions and in the currency of the source country when we extend our tests to the G6 countries.

Motivated by alternative or complementary theories, we control for several destination country characteristics. First, investors may tilt their portfolios away from destination countries in which there are capital controls

3 The earliest FDI years in the UNCTAD FDI database are 1989 for Canada and Japan, 1990 for the United States and the United Kingdom, 1991 for Germany, and 1992 for France. For simplicity, we refer to these data as 1990 FDI for all countries. Since Japan's FDI data in the UNCTAD database are not detailed enough, we use Japanese FDI stock data from Japan's Ministry of Finance. 
(Black 1974). Contemporaneous work by Bekaert and Wang (2009) suggests that in contrast to earlier research, capital controls may still be an important determinant of international portfolio choice. We use two variables to capture the lack of capital controls in destination countries: the Chinn and Ito (2006) capital account openness index and the Bekaert, Harvey, and Lundblad (2005) measure of intensity of equity liberalization. Following Dahlquist et al. (2003) and Kho, Warnock, and Stulz (2009), we control for Inside Ownership, i.e., the value-weighted fraction of closely held shares in destination countries. This control variable is motivated by Stulz (2005), who develops a theory in which company insiders, assumed to be domestic investors, hold a large fraction of shares in countries with poor corporate governance and a high likelihood of government expropriation, leaving fewer shares for atomistic domestic or foreign investors. We also control for other institutional characteristics of destination countries. These variables are motivated by Giannetti and Koskinen (forthcoming), who present a model in which investors from countries with strong investor protection abstain from investing in countries with lower investor protection even when the valuations in these countries are lower. We proxy for investor protection using two variables: Anti-Director Rights from Djankov et al. (2008) and Property Rights from La Porta et al. (1998). We also include a Country Governance variable, defined as the average of the six institutional variables from Kaufmann, Kraay, and Mastruzzi (2006). Following Chan, Covrig, and Ng (2005), we also control for other economic development characteristics of destination countries using stock market capitalization over GDP, stock market turnover, and log of GDP per capita. These data are collected from World Development Reports.

In order to demonstrate the novelty of our results to the literature linking portfolio investment to information or familiarity, we control for geographic, language, and economic proximity following Sarkissian and Schill (2004). We borrow the definition of proximity variables from Acemoglu, Demirguc-Kunt, and Laeven (2008). Geographic proximity is defined as the inverse of the geographic distance in thousands of kilometers between the capitals of source and destination countries. Economic proximity is based on the strength of trade between source and destination countries in the year 2000, defined as exports plus imports between source country and destination country in 2000 divided by the total trade of the source country in 2000. Language proximity of source country $i$ and destination country $j$ is defined as an uncentered correlation as follows. Let $L$ be the number of distinct languages in the entire sample and $S_{i}=\left(S_{i 1}, S_{i 2}, \ldots, S_{i L}\right)$ be the vector of shares of language groups in home country $i$. The language proximity of source country $i$ and destination country $j$ is

$$
f_{i j}=\frac{\sum_{l} S_{i l} S_{j l}}{\sqrt{\left(\sum_{l} S_{i l}^{2}\right)\left(\sum_{l} S_{j l}^{2}\right)}}
$$


For example, the language proximities between the United States and Australia, Canada, Argentina, and Belgium are, respectively, 0.998, 0.929, 0.067 , and 0 .

Table A1 in the Appendix summarizes the definition and sources of our main variables.

\subsection{Descriptive statistics}

Panel A of table 1 presents the time averages of the main variables. Note that from 2001 to 2006, the total weight of stocks from our thirty-eight destination countries in U.S. equity portfolios averaged just $12.58 \%$, as compared with the total weight of such countries in the World Market Portfolio, which averaged $49.73 \%$. This is the home bias puzzle in U.S. equity portfolios. The total of column 3 is equal to $100 \%$ because U.S. FDI in destination countries that are not in the table are ignored. Panel B of table 1 reports the correlations of the time averages listed on the table. Table A2 in the Appendix presents detailed summary statistics for all the variables in the baseline specification.

\subsection{Past FDI and current information flow}

In this section, we provide evidence of a connection between direct measures of information flow and past FDI weights, our proxy for initial information endowment. Following Portes, Rey, and Oh (2001) and Portes and Rey (2005), we use telephone call traffic between the United States and destination countries as a proxy for the amount of information about these countries flowing into the United States. We examine how telephone call traffic in the 2001-2003 period is related to FDI weights in 1990. Telephone call traffic is measured in number of minutes per year or number of messages per year. Columns 1 and 3 of table 2 show that both measures are significantly related to past FDI weights. Note the high $R^{2}$ 's of univariate regressions: 0.64 for number of messages and 0.39 for number of minutes. In addition to telephone call traffic, we use air traffic to proxy for information flow between the United States and destination countries. Column 5 of table 2 shows that the FDI weights in 1990 predict the number of people flying from the United States to the destination countries in the 2001-2003 period. Once again, the correlation between these two variables is very strong: the $R^{2}$ of the univariate regression is 0.67 .

Columns 2, 4, and 6 in table 2 show that the relationship between past FDI and current telephone or air traffic is robust to the inclusion of other explanatory variables. These variables address the possibility that there is more traffic with larger countries, or that the United States simply exchanges more information with and has more FDI in its neighboring countries, and thus proximity is the ultimate driver of the cross-sectional relationship between past FDI and measures of information flow. Using columns 2, 4, and 6, we find that the coefficients of FDI 1990 on telephone minutes, telephone messages, and air traffic regressions are, respectively, $0.084,0.019$, and 0.069 . Since the standard errors 
Table 2

Proxies of information flow versus lagged FDI portfolio weights

\begin{tabular}{|c|c|c|c|c|c|c|}
\hline & \multicolumn{4}{|c|}{ Telephone Traffic (average 2001-2003) } & \multirow{2}{*}{\multicolumn{2}{|c|}{$\begin{array}{c}\text { Air Traffic } \\
\text { (average 2001-2003) } \\
\text { Passengers }\end{array}$}} \\
\hline & \multicolumn{2}{|c|}{ Messages } & \multicolumn{2}{|c|}{ Minutes } & & \\
\hline & (1) & (2) & (3) & (4) & (5) & (6) \\
\hline FDI 1990 & $\begin{array}{l}0.036^{* * * *} \\
(0.011)\end{array}$ & $\begin{array}{l}0.019 * * * \\
(0.005)\end{array}$ & $0.159 * * *$ & $\begin{array}{l}0.084 * * \\
(0.034)\end{array}$ & 0.096 *** & $\begin{array}{l}0.069 * * * * \\
(0.022)\end{array}$ \\
\hline Population (2001-2003) & & $\begin{array}{l}0.037 \text { *** } \\
(0.012)\end{array}$ & & $\begin{array}{l}0.349^{* * *} \\
(0.110)\end{array}$ & & $\begin{array}{c}0.034 \\
(0.034)\end{array}$ \\
\hline GDP (2001-2003) & & $\begin{array}{c}-0.055 \\
(0.04)\end{array}$ & & $\begin{array}{c}-0.793 * * \\
(0.381)\end{array}$ & & $\begin{array}{c}-0.125 \\
(0.116)\end{array}$ \\
\hline Language Proximity & & $\begin{array}{c}0.009 \\
(0.030)\end{array}$ & & $\begin{array}{c}-0.074 \\
(0.205)\end{array}$ & & $\begin{array}{r}-0.004 \\
(0.130)\end{array}$ \\
\hline Geographic Proximity & & $\begin{array}{l}0.227 * * \\
(0.088)\end{array}$ & & $\begin{array}{c}-0.988 \\
(1.147)\end{array}$ & & $\begin{array}{c}-1.085 * * \\
(0.485)\end{array}$ \\
\hline Economic Proximity & & $\begin{array}{l}2.494 \text { *** } \\
(0.567)\end{array}$ & & $\begin{array}{l}29.337 * * * \\
(8.869)\end{array}$ & & $\begin{array}{l}11.785 * * * \\
(2.935)\end{array}$ \\
\hline Constant & $\begin{array}{c}-0.031 \\
(0.022)\end{array}$ & $\begin{array}{c}-0.009 \\
(0.020)\end{array}$ & $\begin{array}{c}0.282^{*} \\
(0.154)\end{array}$ & $\begin{array}{c}0.293 \\
(0.020)\end{array}$ & $\begin{array}{c}0.032 \\
(0.044)\end{array}$ & $\begin{array}{c}0.086 \\
(0.069)\end{array}$ \\
\hline$N$ & 38 & 38 & 38 & 38 & 38 & 38 \\
\hline$R^{2}$ & 0.64 & 0.93 & 0.39 & 0.86 & 0.67 & 0.91 \\
\hline
\end{tabular}

The table shows the results of cross-sectional regressions of proxies for information flow from 38 countries to the United States onto 1990 weights in the U.S. FDI portfolio and control variables. Information flow variables are averaged in the 2001-2003 period. Details of information variables are included in the Appendix. Standard errors robust to heteroskedasticity and are clustered at the destination country level. $* * *, * *$, and * represent significance at the $1 \%, 5 \%$, and $10 \%$ levels, respectively.

of these dependent variables are, respectively, 1.137, 0.201, and 0.521, and the standard deviation $(S D)$ of FDI 1990 is 4.404, a 1 SD increase in FDI 1990 increases telephone minutes, telephone messages, and air traffic in the 20012003 period by $0.33,0.42$, and $0.58 S D$ s, respectively, after controlling for size and proximity.

\section{Determinants of U.S. International Portfolio Allocation}

In this section, we report the results of panel regressions examining how U.S. residents allocate their stock portfolios internationally. We follow Petersen (2009) and report standard errors that are robust to heteroskedasticity and clustered at the destination country level. We focus on the thirty-eight destination countries in table 1 and on the 2001-2006 period, thus having $38 \times 6=228$ data points in total. All regressions include year fixed effects, i.e., a different intercept for each year.

Table 3 reports results of ordinary least squares (OLS) regressions of the weight in the U.S. stock portfolio on our main explanatory variables. Column 1 of table 3 shows that the weight in the U.S. stock portfolio is positively related to the weight in the World Market Portfolio. If a world version of the CAPM held, the coefficient on the World Market Portfolio would be equal to 1. Instead the coefficient is only 0.263 , with a $t$-statistic of 5.71 . The desire to 
Table 3

Preliminary regression results for weight in U.S. stock portfolio

\begin{tabular}{|c|c|c|c|c|c|c|c|}
\hline & (1) & (2) & (3) & (4) & (5) & (6) & (7) \\
\hline World Market Portfolio & $\begin{array}{l}0.263 * * * \\
(0.046)\end{array}$ & $\begin{array}{l}0.190 * * * \\
(0.021)\end{array}$ & $\begin{array}{l}0.192 * * * \\
(0.022)\end{array}$ & $\begin{array}{l}0.186 * * * \\
(0.017)\end{array}$ & $\begin{array}{l}0.187 \text { *** } \\
(0.036)\end{array}$ & $\begin{array}{l}0.220 * * * \\
(0.036)\end{array}$ & $\begin{array}{l}0.189^{\text {*** }} \\
(0.020)\end{array}$ \\
\hline FDI 1990 & & $\begin{array}{l}0.047 * * * \\
(0.017)\end{array}$ & $\begin{array}{l}0.048 * * * \\
(0.019)\end{array}$ & $\begin{array}{l}0.056^{* * * *} \\
(0.017)\end{array}$ & $\begin{array}{l}0.043 * * \\
(0.017)\end{array}$ & $\begin{array}{l}0.042 * * \\
(0.016)\end{array}$ & $\begin{array}{l}0.043^{*} * * \\
(0.016)\end{array}$ \\
\hline Stock Return Volatility & & & $\begin{array}{c}0.186 \\
(0.111)\end{array}$ & $\begin{array}{c}0.203^{*} \\
(0.108)\end{array}$ & $\begin{array}{l}0.255^{* *} \\
(0.107)\end{array}$ & $\begin{array}{l}0.310 * * \\
(0.123)\end{array}$ & $\begin{array}{c}0.135 \\
(0.095)\end{array}$ \\
\hline Telephone Minutes (2001-2003) & & & & $\begin{array}{c}-0.037 \\
(0.043)\end{array}$ & & & \\
\hline Inside Ownership & & & & & $\begin{array}{c}-0.003 * * * \\
(0.001)\end{array}$ & $\begin{array}{r}-0.002^{*} \\
(0.001)\end{array}$ & $\begin{array}{c}-0.004 * * * \\
(0.001)\end{array}$ \\
\hline GDP 1990 & & & & & & $\begin{array}{c}-0.120 \\
(0.086)\end{array}$ & \\
\hline GDP per Capita 1990 & & & & & & & $\begin{array}{c}-0.006 \\
(0.005)\end{array}$ \\
\hline Year effects & + & + & + & + & + & + & + \\
\hline$N$ & 228 & 228 & 228 & 228 & 228 & 228 & 228 \\
\hline$R^{2}$ & 0.84 & 0.91 & 0.91 & 0.91 & 0.91 & 0.92 & 0.92 \\
\hline
\end{tabular}

The table shows results of panel regressions of the weight of thirty-eight countries in the U.S. stock portfolio from 2001 to 2006 . Explanatory variables include weights in the World Market Portfolio, weights in the 1990 U.S. FDI position, and Stock Return Volatility. Year fixed effects are included. Standard errors are robust to heteroskedasticity and are clustered by destination country. $* * *, * *$, and $*$ represent significance at the $1 \%, 5 \%$, and $10 \%$ levels, respectively. 
diversify internationally is not the only factor explaining how investors allocate portfolios across countries.

Column 2 of table 3 adds our novel explanatory variable. Consistent with Van Nieuwerburgh and Veldkamp's (2009), the weight in U.S. 1990 FDI position explains the international portfolio allocation by U.S. residents in the 2001-2006 period. Column 3 adds Stock Return Volatility as a regressor and shows that its coefficient is positive but not statistically significant. Column 4 of table 3 shows that FDI 1990 subsumes the effect of Telephone Traffic measured in minutes, a proxy of current information flow: The coefficient on Telephone Traffic (minutes) is negative and statistically insignificant, whereas the coefficient on FDI 1990 remains large and statistically significant. When FDI 1990 is not included, unreported regressions show that the coefficient on Telephone Traffic is positive and statistically significant at the $1 \%$ level, as one would guess based on the results in Portes and Rey (2005). Similarly, both Telephone Traffic measured in number of messages and Air Traffic are not positive and statistically significant when FDI 1990 is included as a regressor, but become so when FDI 1990 is excluded.

Column 5 of table 3 shows that FDI 1990 is not picking up the effect of current Inside Ownership (a possibility, since they are strongly negatively correlated, as shown in table B2 in the Appendix). The coefficient of FDI 1990 remains economically and statistically significant after the inclusion of Inside Ownership as a control variable. ${ }^{4}$ Moreover, column 4 shows that variations in 1990 FDI weights have a larger effect in 2001-2006 portfolio weights than contemporaneous variations in Inside Ownership. Using the SDs in table A2 and the coefficient estimates in column 4 of table 3 , we find that a $1 S D$ increase in FDI 1990 increases the stock portfolio weight by 0.189 . This is large, compared with the 0.567 sample $S D$ of stock portfolio weights, whereas a $1 S D$ increase in Inside Ownership decreases stock portfolio weight by only 0.096. A $1 S D$ increase in Stock Return Volatility increases the stock portfolio weight by only 0.032 ; thus the economic significance of volatility is rather small. Results of an untabulated regression show that the coefficient on FDI 1990 is still economically and statistically significant if we follow Dahlquist et al. (2003) and "merge" the weight in the World Market Portfolio and the Inside Ownership variables, substituting both by the weight in the World Float Portfolio.

Columns 6 and 7 of table 3 address another concern about our novel explanatory variable. Since the weight of a country in the 1990 U.S. FDI position is correlated with the country's size, it is possible that our measure is simply picking up the size of a destination country's economy. We test this alternative explanation by adding 1990 GDP in trillions of dollars as an additional explanatory variable. The results in column 6 show that the coefficient on FDI

4 In untabulated regressions, we successively orthogonalize FDI 1990 with respect to Inside Ownership and to the weight in the World Market Portfolio. We verify that the coefficient on orthogonalized FDI 1990 remains economically large and statistically significant at $1 \%$. 
1990 remains roughly the same and is still statistically significant when 1990 GDP is added. We run the same regression in column 6 substituting GDP in dollars either by its log or by a country's rank in terms of 1990 GDP, varying from New Zealand (rank = 1) to Japan (rank = 38). The results are qualitatively the same as those reported in column 6. Inclusion of GDP per capita rather than GDP does not affect our conclusion, as shown in column 7.

In summary, the results in table 3 indicate that a country's weight in the 1990 U.S. FDI position is very important in explaining the cross-sectional variation of 2001-2006 weights in U.S. investors' foreign stock portfolios. ${ }^{5}$

\subsection{Complete specification}

The OLS regressions reported in table 3 do not include all the control variables found in the international portfolio choice literature. We add the following variables to the regressions in table 4: three proximity variables, Capital Openness, Equity Liberalization Intensity, Country Governance, Anti-Director Rights, Property Rights, stock market capitalization over GDP, stock market turnover, and log of GDP per capita. After these variables are added, the weight of a country in the U.S. 1990 FDI position still explains that country's weight in the U.S. stock portfolio in the 2001-2006 period. The magnitude of its coefficient increases from 0.042 to 0.073 . The coefficient on Stock Return Volatility is positive, as Van Nieuwerburgh and Veldkamp's (2009) predict, but is not statistically significant. Neither of the measures of lack of capital controls is statistically or economically significant. ${ }^{6}$ The geographic proximity variable is the only statistically significant additional control variable, although it has a counter intuitive sign. Untabulated regression results show that the coefficients on all three proximity variables are positive (but not statistically significant) if FDI 1990 is removed from the regression in column 1 of table 4 . The change in sign of the geographic proximity variable once FDI 1990 is included is consistent with the OLS regression being misspecified, because FDI is endogenously chosen and increases with geographic proximity. We address this issue later in the article.

Table A2 in the Appendix shows that the SDs of the dependent variable, the World Market Portfolio, and FDI 1990 are, respectively, 0.567, 1.956,

\footnotetext{
5 Van Nieuwerburgh and Veldkamp's (2009) theory also predicts that within each destination country, U.S. investors tilt their portfolios toward large stocks and high-beta stocks. Unfortunately, the disaggregated data that give rise to the U.S. CPIS foreign stock holdings are proprietary to the Federal Reserve (see Ammer et al. 2008). Using a much smaller sample of disaggregated U.S. mutual fund holdings (an updated version of the one in Gelos and Wei 2005), we confirm the tilting toward large stocks but do not find tilting toward high beta stocks. However, the cross-country portfolio allocation of our disaggregated holdings data is very different from the CPIS one, which casts doubt on the representativeness of the disaggregated sample.

6 It is unlikely that FDI 1990 is merely proxying for capital openness. In untabulated regressions, we first orthogonalize FDI 1990 with respect to Bekaert, Harvey, and Lundblad's (2005) intensity of equity liberalization measure, Chin and Ito's (2006) capital openness index, and Quinn and Toyoda's(2008) capital openness measure. Then we repeat the regression on column 1 of table 4 using the orthogonalized version of FDI 1990. The coefficient on FDI 1990 is 0.065 , close to the 0.073 we report in table 4 , and still statistically significant at $1 \%$.
} 
Table 4

Regression results for weight in U.S. stock portfolio

\begin{tabular}{|c|c|c|c|c|}
\hline & (1) & (2) & (3) & (4) \\
\hline World Market Portfolio & $\begin{array}{l}0.148^{* * * *} \\
(0.016)\end{array}$ & $\begin{array}{l}0.198 * * * \\
(0.027)\end{array}$ & $\begin{array}{l}0.144 * * * \\
(0.019)\end{array}$ & $\begin{array}{l}0.213 * * * \\
(0.028)\end{array}$ \\
\hline FDI 1990 & $\begin{array}{l}0.073 * * * \\
(0.014)\end{array}$ & & & $\begin{array}{l}0.025 * * \\
(0.011)\end{array}$ \\
\hline Current FDI-FDI 1990 & & & $\begin{array}{l}0.025^{* *} \\
(0.011)\end{array}$ & \\
\hline FDI 1990-FDI 1980 & & & $\begin{array}{l}0.152 \text { *** } \\
(0.032)\end{array}$ & \\
\hline FDI 1980-FDI 1966 & & & $\begin{array}{l}0.043 * * * \\
(0.011)\end{array}$ & \\
\hline FDI 1966 & & $\begin{array}{l}0.057 * * \\
(0.026)\end{array}$ & $\begin{array}{l}0.058^{* * * *} \\
(0.009)\end{array}$ & \\
\hline Stock Return Volatility & $\begin{array}{c}0.219 \\
(0.160)\end{array}$ & $\begin{array}{c}0.201 \\
(0.169)\end{array}$ & $\begin{array}{c}0.171 \\
(0.151)\end{array}$ & $\begin{array}{c}0.155 \\
(0.138)\end{array}$ \\
\hline Language Proximity & $\begin{array}{c}-0.040 \\
(0.102)\end{array}$ & $\begin{array}{c}0.016 \\
(0.155)\end{array}$ & $\begin{array}{c}-0.079 \\
(0.058)\end{array}$ & \\
\hline Geographic Proximity & $\begin{array}{l}-0.712 * * * \\
(0.242)\end{array}$ & $\begin{array}{c}-1.351 * \\
(0.815)\end{array}$ & $\begin{array}{c}-0.165 \\
(0.304)\end{array}$ & \\
\hline Economic Proximity & $\begin{array}{c}0.837 \\
(1.082)\end{array}$ & $\begin{array}{c}1.117 \\
(2.118)\end{array}$ & $\begin{array}{c}0.231 \\
(0.795)\end{array}$ & \\
\hline Capital Openness & $\begin{array}{c}0.005 \\
(0.021)\end{array}$ & $\begin{array}{c}0.029 \\
(0.025)\end{array}$ & $\begin{array}{c}-0.015 \\
(0.019)\end{array}$ & $\begin{array}{c}0.017 \\
(0.020)\end{array}$ \\
\hline Equity Liberalization Intensity & $\begin{array}{c}-0.087 \\
(0.091)\end{array}$ & $\begin{array}{c}-0.059 \\
(0.133)\end{array}$ & $\begin{array}{c}-0.001 \\
(0.078)\end{array}$ & $\begin{array}{c}0.040 \\
(0.080)\end{array}$ \\
\hline Inside Ownership & $\begin{array}{c}-0.004 * * \\
(0.002)\end{array}$ & $\begin{array}{l}-0.005 * * * \\
(0.002)\end{array}$ & $\begin{array}{c}-0.002 * \\
(0.001)\end{array}$ & $\begin{array}{l}-0.005 * * * \\
(0.002)\end{array}$ \\
\hline Country Governance & $\begin{array}{c}0.039 \\
(0.078)\end{array}$ & $\begin{array}{c}0.028 \\
(0.090)\end{array}$ & $\begin{array}{c}0.051 \\
(0.060)\end{array}$ & $\begin{array}{c}-0.004 \\
(0.059)\end{array}$ \\
\hline Anti-Director Rights & $\begin{array}{c}-0.011 \\
(0.026)\end{array}$ & $\begin{array}{c}-0.021 \\
(0.033)\end{array}$ & $\begin{array}{c}-0.001 \\
(0.025)\end{array}$ & $\begin{array}{c}-0.013 \\
(0.029)\end{array}$ \\
\hline Property Rights & $\begin{array}{c}-0.013 \\
(0.033)\end{array}$ & $\begin{array}{c}0.004 \\
(0.047)\end{array}$ & $\begin{array}{c}-0.024 \\
(0.028)\end{array}$ & $\begin{array}{c}0.043 \\
(0.041)\end{array}$ \\
\hline Stock Market Cap/GDP & $\begin{array}{c}-0.024 \\
(0.020)\end{array}$ & $\begin{array}{c}-0.020 \\
(0.031)\end{array}$ & $\begin{array}{c}-0.035 * \\
(0.021)\end{array}$ & $\begin{array}{c}-0.020 \\
(0.030)\end{array}$ \\
\hline Stock Market Turnover & $\begin{array}{c}-0.004 \\
(0.023)\end{array}$ & $\begin{array}{c}0.020 \\
(0.025)\end{array}$ & $\begin{array}{c}-0.008 \\
(0.023)\end{array}$ & $\begin{array}{c}-0.003 \\
(0.027)\end{array}$ \\
\hline Log GDP per Capita & $\begin{array}{c}-0.024 \\
(0.029)\end{array}$ & $\begin{array}{c}-0.029 \\
(0.039)\end{array}$ & $\begin{array}{c}-0.018 \\
(0.027)\end{array}$ & $\begin{array}{c}-0.061 \\
(0.037)\end{array}$ \\
\hline Year effects & + & + & + & + \\
\hline$N$ & 228 & 228 & 228 & 228 \\
\hline$R^{2}$ & 0.94 & 0.90 & 0.95 & 0.91 \\
\hline
\end{tabular}

The table shows results of panel regressions of the weight of thirty-eight countries in the U.S. stock portfolio from 2001 to 2006. Explanatory variables include weights in the World Market Portfolio, weights in lagged U.S. FDI portfolios, and Stock Return Volatility. Several control variables are added. Details of additional control variables are in table A1. Column 4 shows results of a 2SLS regression in which FDI 1990 is instrumented by the proximity variables, the 1990 Corporate Tax Rate, and the average Capital Openness in the 1970-1990 period. Year fixed effects are included. Standard errors are clustered by destination countries and are robust to heteroskedasticity. $* * *, * *$, and $*$ represent significance at the $1 \%, 5 \%$, and $10 \%$ levels, respectively.

and 4.404. Therefore, a $1 S D$ increase in FDI 1990 increases U.S. portfolio weights in the 2001-2006 period by $0.073 \times(4.404 / 0.567)=0.57$ SDs. This is a larger effect than a $1 S D$ increase in the contemporaneous weight on the World Market Portfolio, which increases U.S. FPI weights by only $0.148 \times(1.956 / 0.567)=0.51 S D$. In fact, using the $S D$ s of all regressors in 
column 1 of table 4, one can verify that FDI 1990 is the most economically important variable in describing U.S. portfolio weights in the 2001-2006 period.

In untabulated regressions, we verify that our results are robust to several changes in our specification. For example, results are robust to two alternative ways of defining the dependent variable: using a Fisher transformation of our baseline dependent variable or using the weight of a foreign country in the U.S. foreign (as opposed to total) equity portfolio. Results are also robust to including all the six country governance indices of Kaufmann, Kraay, and Mastruzzi (2006), rather than just using their average; or including either the Anti Self-Dealing Index of Djankov et al. (2008) or the World Bank's Shareholder's Rights Index, instead of using Anti-Director Rights.

\subsection{Other U.S. FDI weights}

We use 1990 FDI weights in our main specification because 1990 is the earliest date in UNCTAD's FDI database. However, earlier U.S. FDI data are available on the Bureau of Economic Analysis (BEA) website. In column 2 of table 4, we use U.S. FDI weights in 1966, the earliest date on BEA's website. The results are qualitatively unchanged: The coefficient on FDI 1966 remains economically large and statistically significant.

Now suppose that the United States had a small FDI position in a destination country in 1990 and that such position increased substantially relative to other destination countries throughout the 1990s (e.g., because that destination country reduced capital controls and privatized a large part of its economy after 1990). In principle, FDIs made after 1990 should also affect portfolio choice during the 2001-2006 period, because they also alter information endowments for subsequent portfolio investment. If that is the case, our regressions in columns 1 and 2 of table 4 suffer from omitted variable problems. To address this possibility in a more general form, in column 3 of table 4, we use four sets of FDI weights as explanatory variables: FDI weights in 1966, the change of FDI weights from 1966 to 1980, the change of FDI weights from 1980 to 1990, and the change of FDI weights from 1990 to 2001-2006. These FDI weight changes are intended to capture the marginal effects of FDI vintages after 1966. Consistent with intuition based on Van Nieuwerburgh and Veldkamp's (2009), all four sets of FDI weights are positive and statistically significant. In untabulated regressions, we obtain similarly strong results using only FDI 1990 and the change of FDI weights from 1990 to current, rather than the four sets of FDI weights in column 3.

\subsection{Endogeneity: Instrumental variables}

It is possible that an omitted variable affecting both lagged FDI weights and current portfolio weights creates an endogeneity problem in our OLS specifications. This omitted variable would have to be slow-moving, since column 2 of 
table 4 shows that 1966 FDI weights are still correlated with portfolio weights in the 2001-2006 period. Moreover, this omitted variable would also have to be orthogonal to our control variables capturing proximity along different dimensions, capital controls, corporate governance, investor protection, country governance, and economic and stock market development levels. Although, in principle, the endogeneity problem can be ruled out by applying instrumental variable (IV) techniques, there are no unequivocally clean instruments in our case.

We address the endogeneity issue by using the three proximity variables (linguistic, geographic, and economic), the 1990 top corporate tax rate, and the average capital openness in the 1970-1990 period as instruments for 1990 FDI weights. A large body of research in international economics indicates that these variables matter for FDI (e.g., Wei 2000; Carr, Markusen, and Maskus 2001). Moreover, columns 1, 2, and 3 of table 4 show that the coefficients on the proximity variables either have the wrong sign or are statistically insignificant in the presence of lagged FDI weights, and untabulated regression results show that none of the proximity variables are statistically significant once lagged FDI weights are excluded from the OLS regression. These results alleviate concerns that proximity variables cannot be used as instruments because they may affect portfolio choice directly.

In the last column of table 4, we report results of a two-stage least squares (2SLS) regression in which lagged FDI weights are instrumented by the three proximity variables, the 1990 corporate tax rate, and the average capital openness from 1970 to 1990 . The top 1990 corporate tax rates are from the Office of Tax Policy Research at the University of Michigan, and the capital openness average is from Chinn and Ito (2006). Table B1 in the Appendix shows that these variables are good instruments for 1990 FDI weights: The $R^{2}$ and partial $R^{2}$ (i.e., only having instruments as explanatory variables) of the first-stage regression are 0.85 and 0.65 , respectively. Column 4 of table 4 shows that, although the magnitude of coefficient on the 1990 U.S. FDI weight drops from 0.073 to 0.025 , the variable remains statistically and economically significant. A $1 S D$ increase in U.S. FDI 1990 weight increases portfolio weights by $0.19 S D$, which makes FDI 1990 the second most economically important explanatory variable, after weight in the World Market Portfolio. To check robustness and address econometric concerns raised by Campa and Kedia (2002), we run GMM and LIML IV regressions, in addition to the 2SLS IV regression of column 4 of table 4 . The results are very similar to those reported.

\subsection{Endogeneity: Change regression}

In this section, we mitigate the effect of a potential time-invariant omitted variable by running change regressions rather than using IVs. We study the change in U.S. foreign portfolio weights from 1994 to 2006, using 1994 data from the Department of Treasury website. Note that, differently from the rest of the 
article, our dependent variable here is the weight on U.S. foreign portfolio only, rather than on the total U.S. portfolio. This is because we do not have data on foreign holdings of U.S. stocks for 1994. For consistency, we measure size by the weight on the (ex-U.S.) World Market Portfolio. Following Kho, Warnock, and Stulz (2009), we allow changes from 1994 to 2006 to depend on the initial level of the country's weight in the U.S. foreign portfolio, and we include explanatory variables both in levels and in changes. Our focus is on the marginal effect of a change in the weight of the FDI position from 1980 to 1990 on the change in FPI weights from 1994 to 2006. The weight on the World Market Portfolio is included as a regressor because Van Nieuwerburgh and Veldkamp's (2009) and our results in table 4 indicate that it should affect foreign portfolio weight changes. Table 5 contains the results.

We find that the change in FDI weights from 1980 to 1990 helps to explain the change in foreign portfolio weights from 1994 to 2006. The coefficient has the expected sign and is statistically significant at the $1 \%$ level: An increase in FDI weights predicts an increase on future stock portfolio weights. The coefficient is economically relevant: a $1 S D$ increase in the change in FDI weights predicts a $0.849 \times(1.192 / 1.444)=0.70 S D$ increase in future FPI weights. The change results are robust to all six specifications in table 5. The coefficient on the changes in the weight on the World Market Portfolio is also statistically significant, has the correct sign in all specifications, and is about two times more economically relevant than the change in FDI weights. Untabulated regressions controlling for changes in each of the six institutional variables in Kaufmann, Kraay, and Mastruzzi (2006) produce similar results. We conclude that lagged FDI weights do not proxy for a time-invariant omitted variable.

\section{Determinants of the International Portfolio Allocation of G6 Countries}

Many empirical analyses of international portfolio choice are based on the holdings of U.S. residents only. Of course, it is impossible to ascertain whether U.S. results carry over to other major developed countries without actually using non-U.S. data. We do this and reproduce our U.S.-only tests using data from all the G6 countries (G7 minus Italy). In table 6, we report results of OLS and IV regressions in which the dependent variable is the weight of a destination country in a G6 country's stock portfolio in each year from 2001 to 2006. These results for the G6 countries are comparable to table 4 results for the U.S. only. There are $38 \times 6 \times 6=1,368$ data points. Year and source country fixed effects are included in the regressions for G6 countries.

In unreported regressions, we compare coefficient estimates in two specifications: including and excluding the United States as a destination country. It turns out that the coefficients of these specifications are very different, even though the samples differ only by 30 data points in a total sample of more than 1,300 data points. This suggests that the United States, being the largest 
Table 5

Regression results for changes in the weight in U.S. foreign stock portfolio

(1)

(5)

(6)

Weight in U.S. FPI portfolio in 1994

$-0.498^{* * *}$

$-0.931 * * *$

$-0.925 * * *$

$-0.966 * * *$

$-0.969 * * *$

$-0.965^{* * *}$

Weight in World Mkt port. Ex-U.S. 1994

$0.571 *$

$0.097)$

$(0.117)$

$0.502 \cdot$

$(0.108)$

$(0.144)$

$\Delta$ (Weight in World Mkt port. Ex-U.S.)

(0.159)

(0.131)

(0.147)

(0.130)

$0.477 * *$

$(0.181)$

$(0.197)$

$0.402 * * *$

$0.484 * *$

$0.431 * *$

$(0.225)$

(0.196)

(0.110)

0.849 ***

$0.403 *$

$0.398 * * *$

FDI 1990-FDI 1980

(0.242)

$(0.298)$

$0.842 * *$

$-0.000$

$(0.220)$

$0.513^{* *}$

$0.513 * * *$

Capital Openness 1994

$(0.001)$

$-0.000$

(0.001)

$-0.001$

(0.005)

0.002

$\Delta$ (Equity Liberalization Intensity)

(0.003)

Inside Ownership 1994

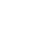

$\Delta$ (Inside Ownership)

Country Governance 1996

$\Delta$ (Country Governance)

Constant

$$
\begin{gathered}
-0.003^{* *} \\
(0.001)
\end{gathered}
$$$$
-0.001
$$$$
(0.001)
$$

$-0.000$

(0.002)

0.009

(0.005)

$0.444 * *$

(0.163)

$0.445^{*}$

$(0.214) \quad(0.207)$

$0.395^{* * * *} \quad 0.397 * * *$

$(0.109)$

$(0.131)$

(0.131)

$\begin{array}{lr}0.835^{* * *} * & 0.839 \\ (0.244) & (0.306)\end{array}$

$-0.001$

(0.001)

$-0.001$

(0.001)

0.002

$(0.009)$

$-0.001$

(0.005)

$(0.005)$
-0.021

$-0.018^{*}$

(0.009)

$-0.009$

$(0.005)$

$(0.009)$

$(0.009)$
-0.000

$-0.000$

(0.001)

(0.001)

$-0.000$

$(0.001)-(0.001)$

$N$
$R^{2}$

38
0.70

38
0.84

38
0.84

38

0.011

(0.007)

0.009
$(0.007)$

The table shows results of a cross-sectional regression of the change in the weight of thirty-eight countries in the U.S. stock portfolio from 1994 to 2006 . Explanatory variables include levels and changes in weights in the World Market Portfolio (ex-U.S.) and levels and changes in the weights on the U.S. FDI portfolio from 1980 to 1990 . Additional control variables are added. Details of additional control variables are in table A1. Standard errors are robust to heteroskedasticity. ***, **, and * represent significance at the $1 \%, 5 \%$, and $10 \%$ levels, respectively. 
Table 6

Regression results for weight in G6 countries' stock portfolios

\begin{tabular}{|c|c|c|}
\hline & OLS & IV \\
\hline World Market Portfolio & $\begin{array}{l}0.163^{* * * *} \\
(0.036)\end{array}$ & $\begin{array}{l}0.168 * * * \\
(0.037)\end{array}$ \\
\hline FDI 1990 & $\begin{array}{l}0.046^{* *} \\
(0.022)\end{array}$ & $\begin{array}{l}0.124 * * * \\
(0.030)\end{array}$ \\
\hline FDI $1990 *$ U.S. destination dummy & $\begin{array}{c}0.011 \\
(0.038)\end{array}$ & $\begin{array}{l}0.117 * * * \\
(0.038)\end{array}$ \\
\hline Stock Return Volatility & $\begin{array}{c}0.200 \\
(0.171)\end{array}$ & $\begin{array}{c}0.292 \\
(0.218)\end{array}$ \\
\hline Language Proximity & $\begin{array}{c}0.048 \\
(0.314)\end{array}$ & \\
\hline Geographic Proximity & $\begin{array}{c}0.059 \\
(0.108)\end{array}$ & \\
\hline Economic Proximity & $\begin{array}{l}9.543^{* * * *} \\
(2.809)\end{array}$ & \\
\hline Capital Openness & $\begin{array}{c}0.043^{*} \\
(0.026)\end{array}$ & $\begin{array}{c}0.032 \\
(0.021)\end{array}$ \\
\hline Equity Liberalization Intensity & $\begin{array}{c}-0.043 \\
(0.075)\end{array}$ & $\begin{array}{c}-0.029 \\
(0.062)\end{array}$ \\
\hline Inside Ownership & $\begin{array}{c}-0.003 \\
(0.003)\end{array}$ & $\begin{array}{c}0.001 \\
(0.002)\end{array}$ \\
\hline Country Governance & $\begin{array}{c}0.051 \\
(0.095)\end{array}$ & $\begin{array}{c}0.046 \\
(0.069)\end{array}$ \\
\hline Anti-Director Rights & $\begin{array}{c}-0.061 * \\
(0.031)\end{array}$ & $\begin{array}{r}-0.055^{*} \\
(0.032)\end{array}$ \\
\hline Property Rights & $\begin{array}{c}-0.040 \\
(0.054)\end{array}$ & $\begin{array}{c}-0.065 \\
(0.055)\end{array}$ \\
\hline Stock Market Cap/GDP & $\begin{array}{c}0.036 \\
(0.043)\end{array}$ & $\begin{array}{c}-0.003 \\
(0.037)\end{array}$ \\
\hline Stock Market Turnover & $\begin{array}{c}0.061^{*} \\
(0.036)\end{array}$ & $\begin{array}{l}0.088 * * \\
(0.039)\end{array}$ \\
\hline Log GDP per Capita & $\begin{array}{c}-0.064 \\
(0.041)\end{array}$ & $\begin{array}{c}0.003 \\
(0.043)\end{array}$ \\
\hline U.S. destination dummy & $\begin{array}{c}-4.594 * * \\
(2.062)\end{array}$ & $\begin{array}{c}-10.024 * * * \\
(2.136)\end{array}$ \\
\hline Year and source effects & + & + \\
\hline$N$ & 1368 & 1368 \\
\hline$R^{2}$ & 0.90 & 0.84 \\
\hline
\end{tabular}

The table shows results of panel regressions of the weights of thirty-eight countries in G6 countries' stock portfolios from 2001 to 2006. Explanatory variables include weights in the World Market Portfolio, weights in the G6 FDI portfolio as of 1990, and Stock Return Volatility. Several control variables are added. In the 2SLS IV regression, FDI 1990 weight and its interaction with the U.S. destination dummy are instrumented by the proximity variables, the 1990 corporate tax rate on destination countries, and the average Capital Openness from 1970 to 1990. Year and source country fixed effects are included. Details of additional control variables are in table A1. Standard errors robust to heteroskedasticity are clustered at the destination country level. ***,**, and * represent significance at the $1 \%, 5 \%$, and $10 \%$ levels, respectively.

recipient of both FDI and FPI investment, is an outlier. ${ }^{7}$ This empirical observation motivates the addition of two control variables: a dummy for the United States as a destination country and the U.S. destination dummy interacted with 1990 FDI weights.

The OLS column of table 6 reports that the coefficient on FDI 1990 is 0.046 , having the same order of magnitude as the 0.073 coefficient in the OLS

7 As of 1990, the United States was the destination of $69 \%, 54 \%, 43 \%, 26 \%$, and $20 \%$ of the total FDI of Canada, Japan, the United Kingdom, Germany, and France, respectively. 
regression using U.S. foreign investments only, which is reported in column 1 of table 4. Using the $S D$ s reported in table A2, a $1 S D$ increase in FDI 1990 increases FPI weights in the 2001-2006 period by $0.046 \times(7.262 / 1.387)=$ $0.24 S D$. FDI 1990 is the third most economically important regressor, behind weights in the World Market Portfolio and Economic Proximity. A $1 S D$ increase in these variables increases FPI weights by 0.75 and $0.40 \mathrm{SDs}$, respectively. Log GDP per capita and Capital Openness come in distant fourth and fifth places, with impacts of -0.06 and 0.04 SDs, respectively. Stock Return Volatility is positive but neither statistically nor economically significant.

The IV column reports the results of a 2SLS regression in which 1990 FDI weights (and its interaction with the U.S. destination dummy) are instrumented by the three proximity variables, the 1990 corporate tax rate, and the average capital openness from 1970 to 1990. The coefficient on FDI 1990 is 0.124 , significantly larger than its 0.025 equivalent in the IV regression using U.S. foreign investments only, as reported in column 4 of table 4 . In light of Van Nieuwerburgh and Veldkamp's (2009) theory, this is consistent with U.S. investors having a larger capacity to process information, perhaps due to a more efficient asset management industry in the United States than in the G6 countries collectively. ${ }^{8}$

The coefficients on the U.S. destination dummy shown in table 6 are negative and large, whereas the coefficients on the dummy interacted with 1990 FDI are positive and significant in the IV regression case. The latter suggests that across the other five G6 countries, those with larger FDI in the United States tend to have relatively larger FPI in the United States. The former suggests that the amount of FPI the other five G6 countries have in the United States is small compared with the size of the United States in world markets.

Note that in contrast to regressions based on U.S. investments only, Inside Ownership is not statistically significant in either of the two regressions in table 6. Consistent with Bekaert and Wang (2009), Capital Openness is positive in both regressions, but only statistically significant in the OLS regression. Stock market turnover is also statistically significant, with the expected positive sign in both OLS and IV specifications. Surprisingly, given the results in Giannetti and Koskinen (forthcoming), the coefficient on Anti-Director Rights is negative and statistically significant in both regressions. One tentative explanation for a nonpositive sign in the Anti-Director Rights variable is as follows. Countries with lower Anti-Director Rights could be appealing, ceteris paribus, to foreign investors if the potential violation of minority shareholders is more harmful to local investors than to foreign investors. This could be the case, for example, if such violations tend to be more prominent in bad states of the local

\footnotetext{
8 The fact that the coefficient on Economic Proximity is significant in the OLS regression in table 6 indicates that portfolio choice may be directly related to Economic Proximity, and therefore it should not be used as an instrument for FDI 1990. In an untabulated IV regression, we remove Economic Proximity from the set of instruments, and the results remain qualitatively similar: FDI 1990 is still an economically and statistically significant determinant of international portfolio choice.
} 
economy: local investors, holding relatively more local stock, would require a larger premium to compensate for this systematic risk. This could lower the equilibrium price of local stock enough to encourage higher participation by more diversified foreign investors. Note that in the strict sense, our results are not inconsistent with Giannetti and Koskinen (forthcoming) because the data and specifications are different. We use CPIS data which are meant to include all FPI of source countries, whereas Giannetti and Koskinen (forthcoming) focus on a smaller sample of institutional investors compiled by Thomson Financial Securities Data. The representativeness of their sample is not clear from their paper. Moreover, our set of source and destination countries differs from theirs.

In sum, the results of the G6 countries' regressions agree with those of U.S.-only regressions: Past FDI is an economically and statistically significant determinant of the cross-country portfolio allocation, which provides support to Van Nieuwerburgh and Veldkamp's (2009) theory.

\section{Additional Robustness Checks}

In this section, we report the results of adding explanatory variables, changing our statistical technique, and changing our dependent variable.

\subsection{Own FDI versus other countries' FDI}

This section addresses a general equilibrium issue absent from the previous analysis. ${ }^{9}$ Van Nieuwerburgh and Veldkamp's (2009) theory focuses on how much investors know relative to other investors. Therefore, it could be the case that even though U.S. FDI in country X generates useful information for later U.S. portfolio investors, these investors choose not to invest relatively more in country $\mathrm{X}$ because they know that several other countries have had larger FDI positions in country $X$. This implies that a country's portfolio weight in a destination country might depend not just on its own FDI but also on the FDI of other source countries.

We address this issue by adding one explanatory variable to our baseline specification. For each source and destination country pair in our sample (six sources and thirty-nine destinations), we compute the weight of that destination country in the aggregate 1990 FDI portfolio of all other source countries. For example, for the United States (source) and Brazil (destination), we first compute the difference between the total FDI liabilities of Brazil as of 1990 and the total U.S. FDI in Brazil in 1990. Then we divide such difference by the total FDI assets of all source countries in 1990 minus the total U.S. FDI assets in 1990. Data on the total 1990 FDI assets and liabilities of all our sample countries, plus eighty additional ones, come from Lane and Milesi-Ferretti

9 We thank an anonymous reviewer for calling our attention to this issue. 
Table 7

Regression results of other countries' FDI weights

Panel A: Weight in stock portfolios

\begin{tabular}{|c|c|c|c|c|}
\hline & \multicolumn{2}{|c|}{ U.S. } & \multicolumn{2}{|c|}{ G6 } \\
\hline & OLS & IV & OLS & IV \\
\hline World Market Portfolio & $\begin{array}{l}0.148 * * * \\
(0.016)\end{array}$ & $\begin{array}{l}0.207 \text { *** } \\
(0.021)\end{array}$ & $\begin{array}{l}0.159 * * * \\
(0.034)\end{array}$ & $\begin{array}{l}0.226 * * * \\
(0.077)\end{array}$ \\
\hline FDI 1990 & $\begin{array}{l}0.077 * * * \\
(0.015)\end{array}$ & $\begin{array}{l}0.024 * * \\
(0.011)\end{array}$ & $\begin{array}{c}0.042 * \\
(0.023)\end{array}$ & $\begin{array}{l}0.177 * * * \\
(0.041)\end{array}$ \\
\hline FDI $1990 *$ U.S. Destination Dummy & & & $\begin{array}{c}0.016 \\
(0.038)\end{array}$ & $\begin{array}{c}0.042 \\
(0.055)\end{array}$ \\
\hline FDI 1990 of all other countries & $\begin{array}{c}-0.007 \\
(0.006)\end{array}$ & $\begin{array}{c}0.016 \\
(0.046)\end{array}$ & $\begin{array}{c}0.013 \\
(0.019)\end{array}$ & $\begin{array}{c}-0.205 \\
(0.145)\end{array}$ \\
\hline Stock Return Volatility & $\begin{array}{c}0.212 \\
(0.159)\end{array}$ & $\begin{array}{c}0.185 \\
(0.172)\end{array}$ & $\begin{array}{c}0.210 \\
(0.178)\end{array}$ & $\begin{array}{c}0.104 \\
(0.278)\end{array}$ \\
\hline Language Proximity & $\begin{array}{c}-0.036 \\
(0.099)\end{array}$ & & $\begin{array}{c}0.045 \\
(0.317)\end{array}$ & \\
\hline Geographic Proximity & $\begin{array}{l}-0.737 * * * \\
(0.245)\end{array}$ & & $\begin{array}{c}0.059 \\
(0.109)\end{array}$ & \\
\hline Economic Proximity & $\begin{array}{l}0.715 \\
(1.170)\end{array}$ & & $\begin{array}{l}9.570 * * * \\
(2.762)\end{array}$ & \\
\hline Capital Openness & $\begin{array}{c}0.006 \\
(0.020)\end{array}$ & $\begin{array}{c}0.013 \\
(0.020)\end{array}$ & $\begin{array}{c}0.040 \\
(0.027)\end{array}$ & $\begin{array}{l}0.075^{* *} \\
(0.038)\end{array}$ \\
\hline Equity Liberalization Intensity & $\begin{array}{c}-0.089 \\
(0.091)\end{array}$ & $\begin{array}{c}0.035 \\
(0.083)\end{array}$ & $\begin{array}{c}-0.044 \\
(0.075)\end{array}$ & $\begin{array}{c}-0.010 \\
(0.117)\end{array}$ \\
\hline Inside Ownership & $\begin{array}{l}-0.004^{* *} \\
(0.002)\end{array}$ & $\begin{array}{c}-0.005 * * * \\
(0.002)\end{array}$ & $\begin{array}{c}-0.003 \\
(0.003)\end{array}$ & $\begin{array}{c}-0.002 \\
(0.004)\end{array}$ \\
\hline Country Governance & $\begin{array}{c}0.040 \\
(0.077)\end{array}$ & $\begin{array}{c}-0.007 \\
(0.065)\end{array}$ & $\begin{array}{c}0.054 \\
(0.094)\end{array}$ & $\begin{array}{c}0.008 \\
(0.157)\end{array}$ \\
\hline Anti-Director Rights & $\begin{array}{c}-0.011 \\
(0.026)\end{array}$ & $\begin{array}{c}-0.012 \\
(0.031)\end{array}$ & $\begin{array}{c}-0.063 * * \\
(0.031)\end{array}$ & $\begin{array}{c}-0.030 \\
(0.050)\end{array}$ \\
\hline Property Rights & $\begin{array}{l}-0.020 \\
(0.035)\end{array}$ & $\begin{array}{c}0.052 \\
(0.057)\end{array}$ & $\begin{array}{c}-0.036 \\
(0.050)\end{array}$ & $\begin{array}{r}-0.120 \\
(0.113)\end{array}$ \\
\hline Stock Market Cap/GDP & $\begin{array}{c}-0.022 \\
(0.019)\end{array}$ & $\begin{array}{c}-0.029 \\
(0.044)\end{array}$ & $\begin{array}{c}0.031 \\
(0.049)\end{array}$ & $\begin{array}{c}0.077 \\
(0.075)\end{array}$ \\
\hline Stock Market Turnover & $\begin{array}{c}-0.001 \\
(0.023)\end{array}$ & $\begin{array}{c}-0.008 \\
(0.033)\end{array}$ & $\begin{array}{c}0.061 \\
(0.037)\end{array}$ & $\begin{array}{l}0.100 * * \\
(0.040)\end{array}$ \\
\hline Log GDP per Capita & $\begin{array}{c}-0.020 \\
(0.029)\end{array}$ & $\begin{array}{r}-0.059^{*} \\
(0.033)\end{array}$ & $\begin{array}{c}-0.066 \\
(0.041)\end{array}$ & $\begin{array}{c}0.031 \\
(0.060)\end{array}$ \\
\hline U.S. destination dummy & & & $\begin{array}{c}-4.826^{* *} \\
(2.115)\end{array}$ & $\begin{array}{c}-6.187 * * \\
(4.258)\end{array}$ \\
\hline $\begin{array}{l}\text { Year effects } \\
\text { Source effects }\end{array}$ & + & + & $\begin{array}{l}+ \\
+\end{array}$ & $\begin{array}{l}+ \\
+\end{array}$ \\
\hline$N$ & 228 & 228 & 1368 & 1368 \\
\hline$R^{2}$ & 0.94 & 0.91 & 0.90 & 0.79 \\
\hline
\end{tabular}

(2006). Abstracting from the impact of the destination country's own weight in its local market, one would expect the coefficient on the additional explanatory variable to be negative. ${ }^{10}$ Table 7 reports our results.

10 A nonnegative coefficient on other source countries' lagged FDI does not necessarily present a challenge to Van Nieuwerburgh and Veldkamp's (2009) theory. Suppose, for example, that all foreign countries increase their FDI in a given destination country $\mathrm{X}$ proportionately, increasing the weight of country $\mathrm{X}$ on all FDI portfolios uniformly. It is possible that this uniform FDI weight increase in all countries leads to a later increase of the weight of country X in all source countries' stock portfolios. When foreign countries hold FDI in country X, they are positioned to reduce their information disadvantage relative to locals, possibly leading to an increase in the weight of country $\mathrm{X}$ in all source countries' stock portfolios, at the expense of a reduction in country X's home bias. 
Table 7

(continued)

Panel B: Change in weight in U.S. foreign stock portfolio

Weight in U.S. FPI portfolio in 1994

$\begin{array}{cc}-0.913 * * * & -0.969 * * * \\ (0.097) & (0.119) \\ 0.536^{* * *} & 0.446 * * * \\ (0.141) & (0.154) \\ 0.518 * * & 0.354 \\ (0.253) & (0.281) \\ 0.408 * * * & 0.443^{* * *} \\ (0.107) & (0.111) \\ 0.877 * * & 0.931 * * * \\ (0.255) & (0.257) \\ -0.000 & -0.000 \\ (0.002) & (0.002) \\ -0.001 & 0.001 \\ (0.002) & (0.002) \\ & -0.002 \\ & (0.001) \\ & -0.001 \\ & (0.001) \\ & 0.004 \\ & (0.005) \\ & -0.001 \\ & (0.003) \\ 0.84 & -0.024 * * \\ & (0.012) \\ & -0.001 \\ & (0.006) \\ & 0.011 \\ & (0.007) \\ & 38 \\ & 0.88 \\ & \\ & \\ & \end{array}$

Weight in World Mkt port. ex-U.S. 1994

$\Delta$ (Weight in World Mkt port. ex-U.S.)

FDI 1980

FDI 1990-FDI 1980

FDI 1980 of all other source countries

FDI 1990-FDI 1980 of all other source countries

Capital Openness 1994

$-0.002$

$\Delta$ (Capital Openness)

$-0.001$

Equity Liberalization Intensity 1994

$\Delta$ (Equity Liberalization Intensity)

Inside Ownership 1994

$\Delta$ (Inside Ownership)

(Inside Ownership)

Constant

Panel A shows results of panel regressions of the weight of thirty-eight countries in the U.S. stock portfolio from 2001 to 2006. Explanatory variables include weights in the World Market Portfolio, weights in lagged U.S. FDI portfolios, and Stock Return Volatility. Several control variables are added. Details of additional control variables are in table A1. Column 4 shows results of a 2SLS regression in which FDI 1990 and the destination country's weight in the 1990 FDI portfolio of all other source countries are instrumented by the proximity variables, the 1990 Corporate Tax Rate, and the average Capital Openness in the 1970-1990 period. Year fixed effects are included. Standard errors are clustered by destination countries and are robust to heteroskedasticity. Panel B shows results of a median regression of the change in the weight of thirty-eight countries in the U.S. stock portfolio from 1994 to 2006. Explanatory variables include levels and changes in weights in the World Market Portfolio (ex-U.S.) and levels and changes in the weights on the U.S. FDI portfolio from 1980 to 1990. $* * *, * *$, and $*$ represent significance at the $1 \%, 5 \%$, and $10 \%$ levels, respectively.

In panel $\mathrm{A}$ of table 7, we add the weight in other source countries' FDI portfolio to the regressions reported in tables 4 and 6. Results in panel A show that FDI 1990 remains significant in all four regressions: United States or G6 portfolios and OLS or IV regressions. The coefficient on the additional variable is not statistically significant in any of the regressions. In the IV regression for the G6 countries, the coefficient is negative with a $t$-stat equal to -1.41 , which corresponds to a $p$-value of 0.16 .

In panel $\mathrm{B}$ of table 7 , we add two explanatory variables to our regression for the change in the weight in the U.S. FPI portfolio from 1994 to 2006. We add the weight of a destination country in the FDI portfolio of all other 
source countries (that is, excluding the United States) in 1980 and the change in the weight of a destination country in the FDI portfolio of all other source countries from 1980 to 1990 . Panel B shows that the coefficient in the change in (lagged) FDI weights barely changes and remains statistically significant, whereas coefficients in the additional variables are not statistically significant.

\subsection{Median regressions}

We also perform median regressions (as opposed to linear regressions) in our baseline OLS specifications. We compute bootstrapped confidence intervals using 10,000 repetitions and clustering by destination country. Panel A of table 8 reproduces the regressions having the stock market weight in the 2001-

Table 8

Median regression results

Panel A: Weight in stock portfolios

\begin{tabular}{|c|c|c|}
\hline 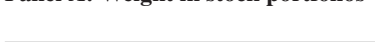 & U.S. & G6 \\
\hline World Market Portfolio & $\begin{array}{l}0.144 * * * \\
(0.045)\end{array}$ & $\begin{array}{l}0.143 * * * \\
(0.036)\end{array}$ \\
\hline FDI 1990 & $\begin{array}{l}0.068^{* *} \\
(0.029)\end{array}$ & $\begin{array}{l}0.070 * * * \\
(0.024)\end{array}$ \\
\hline FDI $1990 *$ U.S. destination dummy & & $\begin{array}{c}0.027 \\
(0.043)\end{array}$ \\
\hline Stock Return Volatility & $\begin{array}{c}0.023 \\
(0.172)\end{array}$ & $\begin{array}{c}0.049 \\
(0.122)\end{array}$ \\
\hline Language Proximity & $\begin{array}{c}-0.052 \\
(0.193)\end{array}$ & $\begin{array}{c}-0.054 \\
(0.180)\end{array}$ \\
\hline Geographic Proximity & $\begin{array}{r}-0.686 \\
(0.719)\end{array}$ & $\begin{array}{c}0.038 \\
(0.101)\end{array}$ \\
\hline Economic Proximity & $\begin{array}{c}1.040 \\
(2.710)\end{array}$ & $\begin{array}{c}5.524 \\
(3.433)\end{array}$ \\
\hline Capital Openness & $\begin{array}{c}-0.008 \\
(0.022)\end{array}$ & $\begin{array}{c}0.017 \\
(0.015\end{array}$ \\
\hline Equity Liberalization Intensity & $\begin{array}{c}-0.072 \\
(0.163)\end{array}$ & $\begin{array}{c}-0.015 \\
(0.072)\end{array}$ \\
\hline Inside Ownership & $\begin{array}{c}-0.002 \\
(0.002)\end{array}$ & $\begin{array}{c}-0.001 \\
(0.001)\end{array}$ \\
\hline Country Governance & $\begin{array}{c}0.047 \\
(0.075)\end{array}$ & $\begin{array}{c}0.025 \\
(0.037)\end{array}$ \\
\hline Anti-Director Rights & $\begin{array}{c}-0.020 \\
(0.036)\end{array}$ & $\begin{array}{c}-0.030 \\
(0.018)\end{array}$ \\
\hline Property Rights & $\begin{array}{c}-0.018 \\
(0.055)\end{array}$ & $\begin{array}{c}0.006 \\
(0.027)\end{array}$ \\
\hline Stock Mkt Cap/GDP & $\begin{array}{c}-0.036 \\
(0.041)\end{array}$ & $\begin{array}{c}-0.018 \\
(0.041)\end{array}$ \\
\hline Stock Mkt Turnover & $\begin{array}{c}0.004 \\
(0.039)\end{array}$ & $\begin{array}{c}0.022 \\
(0.032)\end{array}$ \\
\hline Log GDP per Capita & $\begin{array}{c}-0.004 \\
(0.043)\end{array}$ & $\begin{array}{c}-0.028 \\
(0.025)\end{array}$ \\
\hline U.S. destination dummy & & $\begin{array}{l}-3.897 * * * \\
(1.657)\end{array}$ \\
\hline $\begin{array}{l}\text { Year effects } \\
\text { Source effects }\end{array}$ & + & $\begin{array}{l}+ \\
+\end{array}$ \\
\hline$N$ & 228 & 1368 \\
\hline Pseudo- $R^{2}$ & 0.70 & 0.58 \\
\hline
\end{tabular}


Table 8

(continued)

Panel B: Change in weight in U.S. foreign stock portfolio

Panel B. Change in weight in U.S. foreign stock portfolio

(1) (2)

$0.841 * * *$

(3)

(4)

(5)

Weight in U.S. FPI portfolio in 1994

Weight in World Mkt port. ex-U.S. 1994

$(0.060)$

$(0.070)$

$0.646^{* * *}$

$0.600 * * *$

$-0.835 * * *$

$-0.848 * * *$

(0.068)

$-0.850 * * *$

$-0.832 * * *$

$(0.071)$

$0.624 * * *$

$0.579 * * *$

(0.116)

$0.108)$

$\Delta$ (Weight in World Mkt port. ex-U.S.)

$0.842 * * *$

$(0.068)$

(0.076)

$0.635^{* *}$

$(0.098)$

(0.067)

(0.094)

$0.670 * *$

$0.603^{* * *}$

$0.563 * *$

$0.648^{* * *}$

$0.290 * * *-0.274 * *$

FDI 1980

$(0.057)$

$0.302 * * *$

$0.578 * *$

(0.108)

$(0.057)$

$(0.084)$

$0.302^{*}$

(0.147)

$0.298 * * *$

$0.703 * *$

FDI 1990-FDI 1980

$(0.132)$

$0.617 * * * \quad 0.683$ ***

$(0.091)$

$0.263 * * *$

$0.683 * * * \quad 0.672 * * *$

$(0.096)$

Capital Openness 1994

0.000

$(0.131)$

$0.672 * * *$
$(0.206)$

$0.587 * *$

$\Delta($ Capital Openness $)$

(0.001)

0.000

$(0.001)$

Equity Liberalization Intensity

$-0.003$

$\Delta$ (Equity Liberalization Intensity)

$(0.003)$

$-0.007$

(0.012)

$-0.003$

$\Delta$ (Inside Ownership)

(0.009)

Country Governance 1996

$\Delta$ (Country Governance)

Constant

$$
\begin{array}{cc}
-0.002 & -0.002 \\
(0.001) & (0.001)
\end{array}
$$

38

38

0.45

0.58

$-0.002$

(0.002)

38

0.58
$-0.000$

$(0.001)$

$-0.000$

$-0.002$

0.003

(0.007)

(0.003)

38

38

0.59

38

0.58

Panel A shows results of median fixed-effect panel regressions of the weight of thirty-eight countries in the U.S. and G6 stock portfolios from 2001 to 2006 . Explanatory variables include weights in the World Market Portfolio, weights in the 1990 FDI portfolio, and Stock Return Volatility. Additional control variables and year fixed effects are added. Standard errors are calculated by bootstrap with 10,000 repetitions and clustering by destination. Panel B shows results of a median regression of the change in the weight of thirty-eight countries in the U.S. stock portfolio from 1994 to 2006. Explanatory variables include levels and changes in weights in the World Market Portfolio (ex-U.S.) and levels and changes in the weights on the U.S. FDI portfolio from 1980 to 1990 . ***,**, and * represent significance at the $1 \%, 5 \%$, and $10 \%$ levels, respectively. 
2006 period as the dependent variable, whereas panel B has the regression for changes in foreign portfolio weights from 1994 to 2006. In column 1 of panel A, we reproduce the U.S. regression in column 1 of table 4 . In column 2 we reproduce the G6 regression in column 1 of table 6 . The coefficient on FDI 1990 is positive and statistically significant in both regressions and very close to the one in OLS regressions. This indicates that our main result is not driven by a few outliers. The coefficient on the World Market Portfolio is also statistically significant in both regressions. None of the other explanatory variables, including Inside Ownership, are significant at the $10 \%$ level in median regressions.

Column 1 of panel B in table 8 shows that the change in FDI weights from 1980 to 1990 is statistically significant in explaining changes in FPI weights from 1994 to 2006. Column 2 of panel B reproduces the regression in column 4 of table 5. The results show that changes in FDI weights remain statistically significant after other explanatory variables are included. We conclude that the predictive power of lagged changes in FDI for future foreign portfolio weight is not driven by a few influential observations.

\subsection{CAPM-based bias}

Since our goal is to use the equilibrium model of Van Nieuwerburgh and Veldkamp (2009) to study international portfolio choice, our dependent variable is the weight of a country in the U.S. stock portfolio. This is the same dependent variable of Dahlquist et al. (2003) and analogous to the dependent variables chosen by Portes and Rey (2005), Daude and Fratzscher (2008), and Lane and Milesi-Ferretti (2008). ${ }^{11}$ Instead of using this specification, Ahearne, Griever, and Warnock (2004) and Kho, Warnock, and Stulz (2009) use the CAPM-based foreign bias as the dependent variable. The CAPM-based foreign bias is defined as one minus the ratio of the weight of a country on the U.S. stock portfolio divided by the weight of the country on the World Market Portfolio. Using the CAPM bias as the dependent variable forces the CAPM structure upon the data by restricting the coefficient on the World Market Portfolio. The appropriateness of using one or the other dependent variable can be judged from the perspective of the traditional trade-off between efficiency and robustness. If the CAPM is a fundamentally sound model to describe the data, requiring only ancillary theories to account for marginal deviations, then imposing the CAPM structure on the dependent variable is justifiable. However, if the CAPM is a weak baseline framework to explain international portfolio

11 Lane and Milesi-Ferretti (2008) and Daude and Fratzscher (2008) use the log of the dollar amount of FPI and country dummies. If we had only source country and one year, our approach would be identical to theirs, apart from the $\log$ transformation and the division by a constant. In the U.S. level regressions (tables 3,4 , 7, and 8) we add year dummies to capture differences in the total dollar amount of FPI investment over time. In the G6 regressions (table 6), we add source-country dummies as well, to capture differences in the total amount of FPI across source countries. 
allocation (for example, if information asymmetry or purchasing power parity deviations are too severe), then it may be more appropriate not to force the CAPM structure on the dependent variable and let the data speak for itself.

In this section we report the results of regressions of the CAPM-based foreign bias on lagged FDI weights and other explanatory variables. At a superficial level, one would think that the theory in Van Nieuwerburgh and Veldkamp's (2009) predicts a negative sign for the coefficient on FDI 1990 in a CAPM-bias regression. However, under the joint null hypothesis that Van Nieuwerburgh and Veldkamp's model is correct and FDI 1990 proxies for information endowment, the sign of FDI 1990 in a CAPM-bias regression is undetermined. This is because the weight on the World Market Portfolio, constrained to comply with the CAPM and moved from the right- to the lefthand side of the regression equation, becomes an omitted variable. Therefore, the coefficient on FDI 1990 is biased and inconsistent under the joint null hypothesis. Given our previous empirical results, one can conclude that the coefficient on FDI 1990 is upward biased and thus can change sign from negative to positive. The upward bias arises because weights on 1990 FDI and weights on the World Market Portfolio from 2001 to 2006 are positively correlated, and using the CAPM bias as a dependent variable restricts the coefficient on the World Market Portfolio to be larger than what the data show. As we report in column 1 of table 3, the coefficient of a regression of U.S. portfolio weights on World Market Portfolio weights is only 0.263 (with a standard error of 0.046), much smaller than the CAPM constraint of a coefficient equal to 1 .

The first column of table B2 reports the results of an OLS regression of the CAPM-based foreign bias on explanatory variables, using U.S. foreign investment data only. Note that this regression has a much lower $R^{2}(0.48)$ than the comparable regressions in table 4 (0.94). Therefore, constraining the coefficient on the World Market Portfolio substantially deteriorates the fit to the data. The coefficient on FDI 1990 is positive, small, and statistically insignificant. The second column of table A1 adds the World Market Portfolio, omitted from the first column regression. The coefficient on the World Market Portfolio in the second regression is large and positive. The coefficient on FDI 1990 shifts from positive, small, and insignificant to negative, large, and statistically significant. The regression's $R^{2}$ increases to 0.65 . These results are consistent with our analysis in the preceding paragraph: Using the CAPM bias as a dependent variable erroneously constrains the coefficient on the World Market Portfolio to be too large, generating an omitted variable problem and causing the coefficient on FDI 1990 to be severely upward biased.

For completeness, the remaining columns of table A2 present the results of the IV regression for the U.S. case in column 3 and OLS and IV regressions for the G6 countries in columns 4 and 5. In the IV regressions, 1990 FDI is instrumented by the proximity variables, the 1990 corporate tax rate, 
and the average capital openness from 1970 to 1990. In the U.S. IV case, the $R^{2}$ drops from 0.91 to 0.40 , as compared with the analogous regression in table 4 . For the G6, the $R^{2}$ reductions relative to table 6 are from 0.90 to 0.56 in the OLS case and from 0.84 to 0.39 in the IV case. For the G6 countries collectively, FDI 1990 is statistically significant with the (superficially) expected negative sign in both OLS and IV specifications. FDI 1990 is negative in the U.S. IV case, but not statistically significant in the U.S.-only IV regression. Note that once again in contrast to Giannetti and Koskinen (forthcoming), Anti-Director Rights is positive and statistically significant in both the OLS and the IV regressions for the G6 countries. In contrast to the U.S.-only regressions, Inside Ownership is statistically insignificant in the G6 case.

\subsection{Other information variables}

In table B3 of the Appendix, we report results of OLS and IV regressions for the weight in the U.S. total stock portfolio. Table B3 includes two additional explanatory variables: average yearly Telephone Traffic in 2001-2003, following Portes and Rey (2005), and the fraction of a destination country's stock market that has a public U.S. listing as of 1997. In Ahearne, Griever, and Warnock (2004), the fraction of cross-listing proxies for a reduction of information asymmetries between U.S. and local investors, although some may argue that cross-listing in U.S. exchanges may affect U.S. investors' willingness to purchase foreign stocks because of noninformational reasons (i.e., "bonding" to better U.S. institutions), as in Reese and Weisbach (2002), Doidge, Karolyi, and Stulz (2004), and Lel and Miller (2008). The results show that FDI 1990 remains positive and economically and statistically significant. The coefficients on both telephone call traffic and cross-listing are insignificant. $^{12}$

\subsection{Recent stock market performance}

Perhaps U.S. investors rebalance their portfolios toward countries that have recently outperformed the rest of the world. This could happen because of rational Bayesian updating, as in Brennan and Cao (1997), or because U.S. investors "chase performance" due to behavioral biases (Bohn and Tesar 1996). Since cross-listing activity in the U.S. increases when a foreign market does especially well (Sarkissian and Schill 2008), recent stock market performance could also matter because of U.S. investors' tendency to allocate a larger part of their portfolio to countries that have recently increased their cross-listing activity in U.S. exchanges. We address these possibilities by adding recent

12 In fairness to Ahearne, Griever, and Warnock (2004), note that they use 1997 cross-listing to explain contemporaneous (i.e., 1997) portfolio weights, whereas we use 1997 cross-listing (and 1990 FDI weights) to explain portfolio weights from 2001 to 2006. 
relative stock market performance as an explanatory variable. More specifically, we add the excess (dollar denominated) return of the MSCI index of the destination country over the world MSCI index in the previous five years. For example, for the year 2001, we use the excess return in the 1996-2000 period. Untabulated regression results show that the coefficient on recent stock market performance is statistically insignificant, and the economic magnitude and statistical significance of 1990 FDI weights is unchanged.

\section{Conclusion}

Investors in different countries hold different stock portfolios. A popular explanation for this phenomenon relies on information asymmetry among investors. One criticism of this explanation argues that over time crosscountry information asymmetry should disappear, because investors have incentives to learn about each other's information sets. In a recent paper, Van Nieuwerburgh and Veldkamp (2009) refute this critique by showing that under plausible circumstances, information asymmetry may not only persist but be amplified over time. In their theory, investors choose to learn more and end up investing more in the assets in which they have a (potentially small) initial informational advantage. In order to bring Van Nieuwerburgh and Veldkamp's theory to the data, we conjecture that relative to world investors, U.S. portfolio investors were marginally better endowed with information about countries in which the United States had more FDI. If this is true, the theory predicts that an initial difference in FDIs will lead to a future difference in stock portfolio weights.

Our empirical results support Van Nieuwerburgh and Veldkamp's (2009) theory. After showing that past FDI weights are significantly associated with current proxies for information flow, we document that a country's weight in the U.S. FDI position in 1990 helps to explain that country's weight in the U.S. stock portfolio from 2001 to 2006. Moreover, we show that a change in a country's weight in the U.S. FDI position from 1980 to 1990 helps to predict the change in that country's weight in the U.S. FPI portfolio from 1994 to 2006. Finally, our results hold not only for U.S. holdings of foreign stocks but also for foreign holdings of the G6 countries: The weight of a destination country in a source country's 1990 FDI position helps to explain the weight of that country in the source country's stock portfolio in the 2001-2006 period.

Our results provide fresh evidence consistent with information-based theories of foreign portfolio choice, which had recently lost ground to explanations focusing on cross-country differences in institutional quality. Moreover, we contribute to the literature by showing that early FDI is associated with later FPI, whereas existing research focuses on the contemporaneous choice between these investments given a destination country, thus viewing FDI and FPI as substitutes rather than complements. 


\section{Appendix}

Table A1

Definitions and sources of main variables

Variable Definition and sources

Stock Portfolio Weight Weight of destination country in total stock portfolio of source country in each year from 2001 to 2006, expressed in percent. Sources: CPIS for foreign investments and WDI (World Bank Development Indicators) for domestic market capitalization of source country. Yearly data from 2001 to 2006

FDI 1990 Weight of each destination country in source country FDI portfolio in 1990 (United States and United Kingdom), 1989 (Canada and Japan), 1991 (Germany), or 1992 (France). Unit: percent. Source: UNCTAD and Japan's Ministry of Finance World Market Portfolio Weight of destination country in World Market Portfolio, in percent. Yearly data from 2001 to 2006. Source: WDI

Stock Return Volatility Annualized $S D$ of destination country stock returns in the previous five years minus annualized $S D$ of World portfolio stock returns in the previous five years. Yearly data from 2001 to 2006. Calculated using monthly returns on the MSCI Index of destination countries' stock markets and MSCI World Index. Returns are denominated in the currency of the source country. Source: Datastream

Inside Ownership Fraction of shares that are closely held in destination countries. Value weighted average across individual firms. Yearly data from 2001 to 2005 . We use 2006 values equal to those of 2005. Source: Worldscope (downloaded on October 19, 2006)

Telephone Traffic Number of messages and minutes (both in billions per year) of telephone call traffic between the United States and other countries (all carriers). We use the average in 2001-2003. Source: Federal Communications Commission

Air Traffic Number of outbound passengers from the United States to other countries in millions per year. We use the average in 2001-2003. Source: Bureau of Transportation Statistics

Population $\quad$ Population in hundreds of millions. We use the average in 2001-2003. Source: WDI

GDP

GDP 1990

Geographic Proximity Real gross domestic product in trillions of U.S. dollars. We use the average in 2001-2003. Source: WDI

Real gross domestic product in trillions of U.S. dollars in 1990. Source: WDI One divided by distance (in thousands of kilometers) between capital cities of the host and the destination country. Source:

Acemoglu, Demirguc-Kunt, and Laeven (2008)

Language Proximity Uncentered correlation between share of distinct language groups between the host and the destination country. Let $l \in\{1, \ldots, L\}$ denote the total number of distinct languages in the sample. Let $S_{i}=\left(S_{i 1}, \ldots, S_{i l}, \ldots, S_{i L}\right)$ be the vector of shares of language groups in home country $i$, then language proximity of source country $i$ and destination country $j$ is $\Sigma_{l} S_{i l} S_{j l} \div\left[\left(\Sigma_{l} S_{i l}^{2}\right)\left(\Sigma_{l} S_{j l}^{2}\right)\right]^{1 / 2}$. Source: Acemoglu, Demirguc-Kunt, and Laeven (2008)

Economic Proximity Sum of exports and imports between the source and destination country in the year 2000 divided by total trade of source country in 2000 .

Source: Acemoglu, Demirguc-Kunt, and Laeven (2008)

Corporate Tax Rate 1990 Top marginal tax rate on corporations in 1990. Source: World Tax Database, University of Michigan

Capital Openness Index for openness to capital account transactions. Yearly data from 2001 to 2006. Source: Chinn and Ito (2006)

Equity Liberalization Intensity Ratio of foreign investable securities to total market capitalization. Yearly data from 2001 to 2005. We use 2006 values equal to those of 2005.

Source: Bekaert, Harvey, and Lundblad (2005)

Country Governance Average of six governance indices. The indices are Voice and Accountability, Political Instability and Violence, Government Effectiveness, Regulatory Burden, Rule of Law, and Control of Corruption. Yearly data from 2001 to 2006. Source: Kaufmann, Kraay, and Mastruzzi (2006) 
Table A1

(continued)

Variable Definition and sources

Anti-Director Rights The index ranges from 0 to 6 and is formed by adding 1 when (1) the country allows shareholders to mail their proxy vote, (2) shareholders are not required to deposit their shares prior to the general shareholders' meeting, (3) cumulative voting or proportional representation of minorities, (4) an oppressed minorities mechanism is in place, (5) the minimum percentage of share capital that entitles a shareholder to call for an extraordinary shareholders meeting is less than or equal to $10 \%$, or (6) shareholders have preemptive rights that can be waived only by a shareholders' vote. Source: Djankov et al. (2008)

Property Rights $\quad$ A rating of property rights in each country (on a scale from 1 to 5) in 1997. The score is based, broadly, on the degree of legal protection of private property, the extent to which the government protects and enforces laws that protect private property, the probability that the government will expropriate private property, and the country's legal protection of private property. Source: La Porta et al. (1998)

Stock Market Cap. / GDP Market capitalization as a fraction of GDP. Yearly data from 2001 to 2006. Source: Beck, Demirguc-Kunt, and Levine (2000)

Stock Market Turnover The ratio of total traded volume in a year to the market capitalization. Yearly data from 2001 to 2006. Source: Beck, Demirguc-Kunt, and Levine (2000)

Log GDP per Capita Log of real gross domestic product in U.S. dollars, per capita. Yearly data from 2001 to 2006. Source: WDI 
Table A2

Summary statistics of main variables

Stock World

Stock

Equity

Stock Stock Log

Market Market FDI Return Language Geographic Economic Capital Liberalization Inside Country Director Property Market Market GDP

Weight Portfolio 1990 Volatility Proximity Proximity Proximity Openness Intensity Ownership Governance Rights Rights Cap/GDP Turnover per Cap.

Panel A: Means, medians, $S D$ s

$\begin{array}{lccccc}\text { Mean (U.S.) } & 0.331 & 1.308 & 2.631 & 0.117 & 0.136\end{array}$

$\begin{array}{lllll}0.114 & 0.498 & 0.703 & 0.079 & 0.000\end{array}$

$0.136-0.166$

$\begin{array}{lll}0.166 & 0.022 & 1.433\end{array}$

$\begin{array}{lll}0.166 & 0.022 & 1.433 \\ 0.138 & 0.009 & 2.268\end{array}$

Standard dev.

$\begin{array}{lllll}0.567 & 1.956 & 4.404 & 0.125 & 0.305\end{array}$

0.207

0.038

2.268
1.384

0.876

47.07

1
0.278

48.00
18.14

1.080

0.907

Mean (G6)

$\begin{array}{lllll}0.517 & 2.133 & 2.631 & 0.127 & 0.079\end{array}$

0.358

$228 \quad 228$

228

228

228

46.611

1.100

$0.007 \quad 2.268$

$\begin{array}{llll}1.387 & 6.416 & 7.262 & 0.126\end{array}$

0.000

0.127

0.058

1.382
1368

1
0.278

$\begin{array}{ll}48.000 & 1.100 \\ 18.707 & 0.904\end{array}$

1368

1368

$\begin{array}{ccccc}3.671 & 4.263 & 0.813 & 0.795 & 9.055 \\ 4.000 & 4.000 & 0.586 & 0.627 & 9.518 \\ 1.010 & 0.786 & 0.779 & 0.715 & 1.262 \\ 228 & 228 & 228 & 228 & 228 \\ 3.647 & 4.267 & 0.822 & 0.807 & 9.062 \\ 4.000 & 4.000 & 0.586 & 0628 & 9.518 \\ 1.007 & 0.786 & 0.779 & 0.721 & 1.266 \\ 1368 & 1368 & 1368 & 1368 & 1368\end{array}$

Panel B: correlation matrix

World Market Portfolio $0.930 * 1$

FDI $1990 \quad 0.841 * 0.697 * 1$

Stock Return Volatility $-0.379 *-0.382 *-0.388 *$

$\begin{array}{llllll}\text { Language Proximity } & 0.388 * & 0.272 & 0.565^{*}-0.329 * & 1\end{array}$

$\begin{array}{llllll}\text { Geographic Proximity } & 0.212 & 0.116 & 0.607^{*}-0.176 & 0.364^{*}\end{array}$

$\begin{array}{lllll}\text { Economic Proximity } & 0.490 * & 0.481 * & 0.651 *-0.201 & 0.299\end{array}$

$\begin{array}{llllll}\text { Capital Openness } & 0.338 * & 0.326 * & 0.338 * & -0.649 * & 0.070\end{array}$

$\begin{array}{llllll}\text { Equity Liber. Intens. } \quad 0.255 & 0.273 & 0.230 & -0.340 * & 0.142\end{array}$

\begin{tabular}{lll} 
Inside Ownership & $-0.611^{*}-0.509 *-0.566 *$ & $0.385 *-0.315$ \\
\hline
\end{tabular}

$\begin{array}{lllll}\text { Country Governance } \quad 0.368 * & 0.338 * & 0.361 *-0.644 * 0.243\end{array}$

$\begin{array}{llllll}\text { Anti-Director Rights } & 0.235 & 0.283 & 0.159 & -0.101 & 0.262\end{array}$

$\begin{array}{llllll}\text { Property Rights } & 0.342 * & 0.318 & 0.325 * & -0.370 * & 0.186\end{array}$

$\begin{array}{llllll}\text { Stock Market Cap/GDP } & 0.219 & 0.258 & 0.192 * & -0.232 & 0.037\end{array}$

\begin{tabular}{lllllr} 
Stock Market Turnover & 0.185 & 0.177 & 0.076 & 0.191 & -0.027 \\
Log GDP per Capita & 0.423 & $0.427 *$ & $0.379 *$ & $-0.549 *$ & 0.079 \\
\hline
\end{tabular}

$0.748^{*}$

$0.161 \quad 0.149 \quad 1$

$\begin{array}{rrrr}0.161 & 0.149 & 1 & \\ -0.009 & 0.165 & 0.502 * & 1\end{array}$

$\begin{array}{llll}-0.272 & -0.235 & -0.422 * & 0.285\end{array}$

$\begin{array}{llll}0.125 & 0.126 & 0.764 * & 0.688 *\end{array}$

$\begin{array}{llll}-0.104 & 0.099 & -0.086 & 0.227\end{array}$

$\begin{array}{llll}0.051 & 0.113 & 0.525 * & 0.414\end{array}$

$-0.024=0.003-0.244=0.333 *$

$\begin{array}{llll}-0.108 & -0.018 & -0.181 & -0.101\end{array}$

$0.776 * 0.599 *$

1

$-0.623^{*} \quad 1$

$\begin{array}{lll}-0.025 & 0.115 & 1\end{array}$

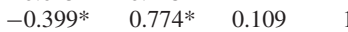

$\begin{array}{lllll}-0.242 & 0.403 * & 0.367 * & 0.367 * & 1\end{array}$

$\begin{array}{llllll}-0.193 & 0.025 & 0.355^{*} & -0.069 & -0.070 & 1\end{array}$

$\begin{array}{lllllll}-0.628 * & 0.861 * & -0.129 & 0.666^{*} & 0.367 * & -0.069 & 1\end{array}$

Panel B presents correlations among time averages (from 2001 to 2006) of explanatory variables used in the article (for U.S. case only). * indicates significance at the 5\% level. 
Table B1

First stage regression results for IV for FDI weight 1990

Language Proximity $3.241^{*}$

Geographic Proximity

$12.255^{* * *}$

Economic Proximity

Capital Openness (1970-1990)

Corporate Tax Rate 1990

Year effects

N

$R^{2}$

Partial $R^{2}$

The table shows results of the first-stage regression results for table 3, column 7. Only the coefficients on IVs are shown. The dependent variable is the weight of thirty-eight countries in the U.S. 1990 FDI position. Instruments are variables representing proximity and by the corporate tax rate in 1990. Coefficients on non-instruments are omitted. Standard errors are clustered at the destination country level. ***,**, and * represent significance at the $1 \%, 5 \%$, and $10 \%$ levels, respectively. 
Table B2

Regression results for CAPM-based foreign bias

\begin{tabular}{|c|c|c|c|c|c|}
\hline & \multicolumn{3}{|c|}{ U.S. } & \multicolumn{2}{|c|}{ G6 } \\
\hline & OLS & OLS & IV & OLS & IV \\
\hline World Market Portfolio & & $\begin{array}{l}0.064 * * * \\
(0.011)\end{array}$ & & & \\
\hline FDI 1990 & $\begin{array}{c}0.001 \\
(0.006)\end{array}$ & $\begin{array}{c}-0.018 * * * \\
(0.006)\end{array}$ & $\begin{array}{r}-0.010 \\
(0.008)\end{array}$ & $\begin{array}{c}-0.025^{* *} \\
(0.011)\end{array}$ & $\begin{array}{c}-0.072 * * * \\
(0.023)\end{array}$ \\
\hline FDI 1990 * U.S. destination dummy & & & & $\begin{array}{l}0.029 * * \\
(0.012)\end{array}$ & $\begin{array}{l}0.073^{* * * *} \\
(0.028)\end{array}$ \\
\hline Stock Return Volatility & $\begin{array}{c}-0.228 \\
(0.142)\end{array}$ & $\begin{array}{c}-0.118 \\
(0.134)\end{array}$ & $\begin{array}{c}-0.231 \\
(0.154)\end{array}$ & $\begin{array}{c}-0.331 \\
(0.226)\end{array}$ & $\begin{array}{c}-0.534^{*} \\
(0.299)\end{array}$ \\
\hline Language Proximity & $\begin{array}{c}-0.000 \\
(0.052)\end{array}$ & $\begin{array}{c}0.023 \\
(0.052)\end{array}$ & & $\begin{array}{c}0.032 \\
(0.110)\end{array}$ & \\
\hline Geographic Proximity & $\begin{array}{c}0.156 \\
(0.173)\end{array}$ & $\begin{array}{l}0.580^{* * * *} \\
(0.096)\end{array}$ & & $\begin{array}{c}-0.147 * * * \\
(0.045)\end{array}$ & \\
\hline Economic Proximity & $\begin{array}{c}-1.667 \\
(1.344)\end{array}$ & $\begin{array}{c}-3.226 * * * \\
(0.452)\end{array}$ & & $\begin{array}{c}-0.587 \\
(0.665)\end{array}$ & \\
\hline Capital Openness & $\begin{array}{c}-0.021 \\
(0.015)\end{array}$ & $\begin{array}{r}-0.026^{*} \\
(0.013)\end{array}$ & $\begin{array}{c}-0.012 \\
(0.019)\end{array}$ & $\begin{array}{c}-0.022 * \\
(0.013)\end{array}$ & $\begin{array}{r}-0.007 \\
(0.021)\end{array}$ \\
\hline Equity Liber. Intens. & $\begin{array}{c}-0.042 \\
(0.088)\end{array}$ & $\begin{array}{c}-0.005 \\
(0.069)\end{array}$ & $\begin{array}{c}-0.071 \\
(0.084)\end{array}$ & $\begin{array}{c}-0.072 \\
(0.046)\end{array}$ & $\begin{array}{c}0.009 \\
(0.072)\end{array}$ \\
\hline Inside Ownership & $\begin{array}{l}0.003 * * \\
(0.001)\end{array}$ & $\begin{array}{l}0.004 * * * \\
(0.001)\end{array}$ & $\begin{array}{c}0.002 \\
(0.002)\end{array}$ & $\begin{array}{c}0.001 \\
(0.002)\end{array}$ & $\begin{array}{c}-0.002 \\
(0.003)\end{array}$ \\
\hline Country Governance & $\begin{array}{c}-0.031 \\
(0.086)\end{array}$ & $\begin{array}{c}0.005 \\
(0.063)\end{array}$ & $\begin{array}{c}-0.011 \\
(0.068)\end{array}$ & $\begin{array}{c}-0.122^{* *} * \\
(0.056)\end{array}$ & $\begin{array}{c}-0.209^{* *} * \\
(0.085)\end{array}$ \\
\hline Anti-Director Rights & $\begin{array}{c}0.008 \\
(0.031)\end{array}$ & $\begin{array}{c}-0.007 \\
(0.022)\end{array}$ & $\begin{array}{c}-0.001 \\
(0.025)\end{array}$ & $\begin{array}{l}0.058 * * \\
(0.022)\end{array}$ & $\begin{array}{l}0.078^{* * * *} \\
(0.022)\end{array}$ \\
\hline Property Rights & $\begin{array}{c}0.023 \\
(0.039)\end{array}$ & $\begin{array}{c}0.028 \\
(0.024)\end{array}$ & $\begin{array}{c}0.029 \\
(0.046)\end{array}$ & $\begin{array}{c}0.031 \\
(0.031)\end{array}$ & $\begin{array}{c}0.072 \\
(0.043)\end{array}$ \\
\hline Stock Market Cap/GDP & $\begin{array}{c}0.011 \\
(0.019)\end{array}$ & $\begin{array}{c}0.004 \\
(0.012)\end{array}$ & $\begin{array}{c}0.021 \\
(0.015)\end{array}$ & $\begin{array}{c}-0.008 \\
(0.011)\end{array}$ & $\begin{array}{c}-0.002 \\
(0.016)\end{array}$ \\
\hline Stock Market Turnover & $\begin{array}{c}-0.002 \\
(0.017)\end{array}$ & $\begin{array}{c}-0.012 \\
(0.017)\end{array}$ & $\begin{array}{c}-0.006 \\
(0.018)\end{array}$ & $\begin{array}{c}-0.037 * * \\
(0.018)\end{array}$ & $\begin{array}{r}-0.038 \\
(0.025)\end{array}$ \\
\hline Log GDP per Capita & $\begin{array}{c}0.005 \\
(0.038)\end{array}$ & $\begin{array}{c}-0.024 \\
(0.031)\end{array}$ & $\begin{array}{c}-0.020 \\
(0.034)\end{array}$ & $\begin{array}{c}0.051 \\
(0.034)\end{array}$ & $\begin{array}{c}0.043 \\
(0.041)\end{array}$ \\
\hline U.S. destination dummy & & & & $\begin{array}{c}0.076 \\
(0.171)\end{array}$ & $\begin{array}{c}-0.126 \\
(0.502)\end{array}$ \\
\hline Year effects & + & + & + & + & + \\
\hline $\begin{array}{l}\text { Source effects } \\
N\end{array}$ & 228 & 228 & 228 & $\begin{array}{c}+ \\
1368\end{array}$ & $\begin{array}{c}+ \\
1368\end{array}$ \\
\hline$R^{2}$ & 0.48 & 0.65 & 0.40 & 0.56 & 0.39 \\
\hline
\end{tabular}

The table shows results of panel regressions of the CAPM-based foreign bias of thirty-eight countries in G6 countries' stock portfolios from 2001 to 2006. The bias is defined as one minus the ratio between the weight of the destination country in the source country's portfolio divided by its weight in the World Market Portfolio. Explanatory variables include weights in the G6 countries' FDI portfolios as of 1990 and Stock Return Volatility in destination countries. Several control variables are added. In the IV regressions, the FDI 1990 weights are instrumented by the proximity variables, the 1990 corporate tax rate, and the average Capital Openness from 1970 to 1990 . Year and source country fixed effects are included. Standard errors are clustered by destination countries and robust to heteroskedasticity. $* * *, * *$, and $*$ represent significance at the $1 \%, 5 \%$, and $10 \%$ levels, respectively. 
Table B3

Regression results including Telephone Traffic and cross-listing in U.S. exchanges

\begin{tabular}{|c|c|c|}
\hline & OLS & IV \\
\hline World Market Portfolio & $\begin{array}{l}0.169 * * * \\
(0.020)\end{array}$ & $\begin{array}{l}0.200 \text { *** } \\
(0.023)\end{array}$ \\
\hline FDI 1990 & $\begin{array}{l}0.063 * * * \\
(0.015)\end{array}$ & $\begin{array}{c}0.036^{*} \\
(0.021)\end{array}$ \\
\hline Telephone Traffic (minutes) & $\begin{array}{c}0.079 \\
(0.043)\end{array}$ & $\begin{array}{c}-0.003 \\
(0.046)\end{array}$ \\
\hline Fraction cross-listed 1997 & $\begin{array}{c}0.119 \\
(0.086)\end{array}$ & $\begin{array}{c}0.085 \\
(0.107)\end{array}$ \\
\hline Stock Return Volatility & $\begin{array}{r}0.322 * \\
(0.160)\end{array}$ & $\begin{array}{c}0.209 \\
(0.130)\end{array}$ \\
\hline Language Proximity & $\begin{array}{c}-0.080 \\
(0.097)\end{array}$ & \\
\hline Geographic Proximity & $\begin{array}{c}-0.597 \\
(0.224)\end{array}$ & \\
\hline Economic Proximity & $\begin{array}{c}-1.420 \\
(1.574)\end{array}$ & \\
\hline Capital Openness & $\begin{array}{c}-0.001 \\
(0.020)\end{array}$ & $\begin{array}{c}0.008 \\
(0.017)\end{array}$ \\
\hline Equity Liberalization Intensity & $\begin{array}{c}-0.143 \\
(0.092)\end{array}$ & $\begin{array}{c}0.002 \\
(0.074)\end{array}$ \\
\hline Inside Ownership & $\begin{array}{c}-0.004 * * \\
(0.002)\end{array}$ & $\begin{array}{c}-0.004^{* * * *} \\
(0.001)\end{array}$ \\
\hline Country Governance & $\begin{array}{c}0.028 \\
(0.050)\end{array}$ & $\begin{array}{c}0.013 \\
(0.058)\end{array}$ \\
\hline Anti-Director Rights & $\begin{array}{c}0.001 \\
(0.028)\end{array}$ & $\begin{array}{c}-0.009 \\
(0.028)\end{array}$ \\
\hline Property Rights & $\begin{array}{c}0.013 \\
(0.034)\end{array}$ & $\begin{array}{c}0.029 \\
(0.033)\end{array}$ \\
\hline Stock Market Cap/GDP & $\begin{array}{c}-0.025 \\
(0.024)\end{array}$ & $\begin{array}{c}-0.016 \\
(0.029)\end{array}$ \\
\hline Stock Market Turnover & $\begin{array}{c}-0.016 \\
(0.024)\end{array}$ & $\begin{array}{c}0.002 \\
(0.024)\end{array}$ \\
\hline Log GDP per Capita & $\begin{array}{c}-0.010 \\
(0.029)\end{array}$ & $\begin{array}{c}-0.050 * \\
(0.028)\end{array}$ \\
\hline Year effects & + & + \\
\hline$N$ & 228 & 228 \\
\hline$R^{2}$ & 0.94 & 0.92 \\
\hline
\end{tabular}

The table shows panel regression results of weights of thirty-eight countries in the U.S. portfolio from 2001 to 2006. Explanatory variables include weights in the world market portfolio, weights in the U.S. FDI portfolio as of 1990, and Stock Return Volatility. Several control variables are added. The 2SLS IV regressions use the proximity variables, the 1990 corporate tax rate, and the average capital openness from 1970 to 1990 as instruments for the FDI 1990. Year fixed effects are included. Standard errors are clustered by destination countries and are robust to heteroskedasticity. $* * *, * *$, and $*$ represent significance at the $1 \%, 5 \%$, and $10 \%$ levels, respectively. 


\section{References}

Acemoglu, D., A. Demirguc-Kunt, and L. Laeven. 2008. Democracy and Institutions. Mimeo.

Ahearne, A. G., W. L. Griever, and F. E. Warnock. 2004. Information Costs and Home Bias: An Analysis of U.S. Holdings of Foreign Equities. Journal of International Economics 62:313-36.

Ammer, J., S. B. Holland, D. C. Smith, and F. E. Warnock. 2008. Why Do U.S. Cross-Listings Matter? International Finance Discussion Paper \#930. Federal Reserve Board.

Beck, T., A. Demirguc-Kunt, and R. Levine. 2000. A New Database on Financial Development and Structure. World Bank Economic Review 14:597-605.

Bekaert, G., and X. Wang. 2009. Home Bias Revisited. Working Paper.

Bekaert, G., C. R. Harvey, and C. T. Lundblad. 2005. Does Equity Market Liberalization Spur Growth? Journal of Financial Economics 77:3-56.

Black, F. 1974. International Capital Market Equilibrium with Investment Barriers. Journal of Financial Economics 1(4):337-52.

Bohn, H., and L. Tesar. 1996. U.S. Equity Investment in Foreign Markets: Portfolio Rebalancing or Return Chasing? American Economic Review 86(2):77-81.

Brennan, M. J., and H. H. Cao. 1997. International Portfolio Investment Flows. Journal of Finance 52(5): $1851-80$.

Chan, K., V. Covrig, and L. Ng. 2005. What Determines the Domestic Bias and Foreign Bias? Evidence from Mutual Fund Equity Allocations Worldwide. Journal of Finance 60:1495-534.

Campa, J. M., and S. Kedia. 2002. Explaining the Diversification Discount. Journal of Finance 57(4):1731-62.

Carr, D. L., J. T. Markusen, and K. E. Maskus. 2001. Estimating the Knowledge-Capital Model of the Multinational Enterprise. American Economic Review 91(3):693-708.

Chinn, M., and H. Ito. 2006. What Matters for Financial Development? Capital Controls, Institutions, and Interactions. Journal of Development Economics 61(1):163-92.

Dahlquist, M., L. Pinkowitz, R. M. Stulz, and R. Williamson. 2003. Corporate Governance and the Home Bias. Journal of Financial and Quantitative Analysis 38(1):87-109.

Daude, C., and M. Fratzscher. 2008. The Pecking Order of Cross-Border Investment. Journal of International Economics 74:94-119.

Djankov, S., R. LaPorta, F. López-de-Silanes, and A. Shleifer. 2008. The Law and Economics of Self-Dealing. Journal of Financial Economics 88(3):430-65.

Doidge, C., G. A. Karolyi, and R. M. Stulz. 2004. Why Are Foreign Firms Listed in the U.S. Worth More? Journal of Financial Economics 71:205-38.

Gelos, G., and S.-J. Wei. 2005. Transparency and International Portfolio Holdings. Journal of Finance 60(6):2987-3020.

Giannetti, M., and Y. Koskinen. Forthcoming. Investor Protection, Equity Returns, and Financial Globalization. Journal of Financial and Quantitative Analysis.

Gherig, T. P. 1993. An Information Based Explanation of the Domestic Bias in International Equity Investment. Scandinavian Journal of Economics 21:7-109.

Goldstein, I., and A. Razin. 2006. An Information-Based Trade-Off Between Foreign Direct Investment and Foreign Portfolio Investment. Journal of International Economics 70:271-95.

Grauer, F. L. A., R. H. Litzenberger, and R. E. Stehle. 1976. Sharing Rules and Equilibrium in an International Market under Uncertainty. Journal of Financial Economics 3:233-56. 
Kang, J., and R. M. Stulz. 1997. Why Is There a Home Bias? An Analysis of Foreign Portfolio Equity Ownership in Japan. Journal of Financial Economics 46:3-28.

Karolyi, G. A., and R. M. Stulz. 2003. Are Financial Assets Priced Locally or Globally? In G. Constantinides, R. Stulz, and M. Harris (eds.), Handbook of the Economics of Finance, vol. 1B, 975-1020. Amsterdam: NorthHolland.

Kaufmann, D., A. Kraay, and M. Mastruzzi. 2006. Governance Matters III: Governance Indicators for 19962002. World Bank Policy Research Working Paper No. 3106.

Kho, B. C., F. E. Warnock, and R. M. Stulz. 2009. Financial Globalization, Governance, and the Evolution of the Home Bias. Journal of Accounting Research 47(2):597-635.

Lane, P. R., and G. M. Milesi-Ferretti. 2006. The External Wealth Mark II: Revised and Extended Estimates of Foreign Assets and Liabilities, 1970-2004. IMF Working Paper.

Lane, P. R., and G. M. Milesi-Ferretti. 2008. International Investment Patterns. Review of Economics and Statistics 90(3):538-49.

La Porta, R., F. Lopez-de-Silanes, A. Shleifer, and R. Vishny. 1998. Law and Finance. Journal of Political Economy 106:1113-45.

Lel, U., and D. P. Miller. 2008. International Cross-Listing, Firm Performance, and Top Management Turnover: A Test of the Bonding Hypothesis. Journal of Finance 58(4):1897-937.

Petersen, M. A. 2009. Estimating Standard Errors in Finance Panel Data Sets: Comparing Approaches. Review of Financial Studies 22:435-80.

Portes, R., and H. Rey. 2005. The Determinants of Cross Border Equity Flows. Journal of International Economics 65:269-96.

Portes, R., H. Rey, and Y. Oh. 2001. Information and Capital Flows: The Determinants of Transactions in Financial Assets. European Economic Review 45:783-96.

Quinn, Denis P., and A. M. Toyoda. 2008. Does Capital Account Liberalization Lead to Growth? Review of Financial Studies 21(3):1403-49.

Razin, A., and E. Sadka. 2007. Foreign Direct Investment: Analysis of Aggregate Flows. Princeton, NJ: Princeton University Press.

Razin, A., E. Sadka, and C. Yuen. 1998. A Pecking Order of Capital Flows and International Tax Principles. Journal of International Economics 44:45-68.

Razin, A., E. Sadka, and C. Yuen. 1999. Excessive FDI Flows under Asymmetric Information. NBER Working Paper \#7400.

Reese, W., and M. Weisbach. 2002. Protection of Minority Shareholders Interests, Cross-Listings in the United States, and Subsequent Equity Offerings. Journal of Financial Economics 66(1):65-104.

Sarkissian, S., and M. Schill. 2004. The Overseas Listing Decision: New Evidence of Proximity Preference. Review of Financial Studies 17:769-809.

Sarkissian, S., and M. Schill. 2008. Cross Listing Waves. Mimeo.

Stulz, R. M. 2005. The Limits of Financial Globalization. Journal of Finance 60(4):1595-638.

Van Nieuwerburgh, S., and L. Veldkamp. 2009. Information Immobility and the Home Bias Puzzle. Journal of Finance 64(3):1187-215.

Wei, S.-J. 2000. How Taxing Is Corruption on International Investors? Review of Economics and Statistics 82(1):1-11. 